\title{
Nenets migration in the landscape: impacts of industrial development in Yamal peninsula, Russia
}

\author{
Anna Degteva ${ }^{1,2,3}$ and Christian Nellemann ${ }^{4 *}$
}

\begin{abstract}
Worldwide, traditional pastoralists are facing challenges of industrial development and competitive land use interfering with their nomadic lives. The Yamal peninsula in western Siberia, a homeland of nomadic Nenets reindeer herders, has been subjected to the Bovanenkovo gas field industrial development since the 1980s. We quantitatively assess how industrial development impacts Nenets migration routes and camp sites and discuss implications for their quality of life. In cooperation with herders, we mapped 21 migration routes and followed two reindeer herder brigades for 15 weeks in July 2008 to August 2009, providing insight into both the social and physical challenges facing Nenets herders. Terrain ruggedness, willow cover, migration routes and camp (chum) sites were recorded on $2 \times 2 \mathrm{~km}$ grid cells on topographic maps. Rugged terrain with willows ( $31 \%$ of the study area), which is land particularly suitable and valuable for reindeer husbandry, contained nearly $61 \%$ of all migration routes. All clusters $\left(>8 \mathrm{~km}^{2}\right.$ ) of rugged terrain were used for grazing, migration and camp sites, reflecting few alternative land opportunities. Many 1- to 3-km narrow passages of such terrain created natural 'bottlenecks' for Nenets migrations in the Yamal landscape. These bottlenecks, used by three to six different reindeer brigades, are crucial for the herders, while competition for land with industrial developers within these areas is particularly high. The physical footprint of Bovanenkovo installations is small, but for the three herding units migrating through these bottlenecks, the industrial development resulted in blockage of two out of four possible routes, loss of major grazing areas and subsequent loss of access to at least 18 traditional camp sites and one sacred site along their traditional route. The combined actions of physical and social impacts from industrial development have reduced migration opportunities and the quality and access to natural resources in the herding cycle. This has thus affected the lives and well-being of indigenous herders in Yamal.
\end{abstract}

Keywords: Herders; Indigenous; Impact assessment; Infrastructure; Oil and gas; Nomadic; Reindeer; Siberia

\section{Background}

Traditional pastoralists are confronted with increasing competition and possible loss of seasonal pastures as infrastructure such as roads, pipelines, power lines and dams, along with urban development and settlement, interferes with migrations (UNEP 2001; Vistnes et al. 2009; Nkedianye et al. 2011; Raziq et al. 2011).

Across the past four decades, the Arctic, home to numerous indigenous peoples, has increasingly received attention for its rising role in the global energy and mineral supply (UNEP 2001, 2010). The Yamal-Nenets Autonomous Okrug - with approximately $90 \%$ of Russia's

\footnotetext{
* Correspondence: christian.nellemann@grida.no

${ }^{4}$ United Nations Environment Programme/GRID-Arendal, Lillehammer 2624, Norway

Full list of author information is available at the end of the article
}

and $20 \%$ of the world's gas production - is strategically important for the Russian Federation and European energy supply (AMAP 2008). The Yamal peninsula is increasingly exposed to a network of developing infrastructure (Kumpula et al. 2012).

These regions are also a home to a diversity of both indigenous peoples and rich natural resources. Reindeer (Rangifer tarandus tarandus) husbandry has existed for over 2,000 years (Federova 2003), and at least 20 different Arctic indigenous people are still partly or fully nomadic and reliant on reindeer herding for their livelihoods, cultural identity and food security (Turi 2002).

As oil and gas production takes place across the traditional lands of indigenous hunters or herders, the development also influences wildlife and herders directly, such as by impacting migration patterns and range use 
(Stammler 2005, 2011; Forbes et al. 2009; Kumpula et al. 2011). Indeed, the vast majority of these developing complexes consist of expanding infrastructure networks comprising elevated gravel roads, pipelines, power lines, drill pads and production and support facilities, with related human traffic and transport, including vehicles and air traffic (Forbes 1999; Forbes et al. 2009; Kumpula et al. 2011; Magga et al. 2011). There is already substantial documentation of Rangifer avoidance to a range of human transportation and settlement infrastructure and subsequent habitat loss for wild reindeer and caribou, as well as semi-domesticated reindeer (Wolfe et al. 2000; Cameron et al. 2005; Vistnes and Nellemann 2009; Anttonen et al. 2011).

Most Arctic industrial development may be substantial locally but typically covers less than $1 \%$ to $2 \%$ of the territory in which development takes place (Vistnes and Nellemann 2009). Furthermore, several studies have shown that important grazing ranges are lost disproportionately and become unavailable, as development tends to target certain types of terrain for construction (Nellemann and Cameron 1998, 1996). Development has also been shown to impact much greater areas beyond that of the initial footprint, including abandonment of calving grounds by caribou and reindeer (Joly et al. 2006). While several valuable studies have assessed the situation for Nenets herders exposed to development, few quantitative data have actually shown to what extent this development actually impacts the reindeer herder migrations and access to grazing land and the 'quality' of pastures from the herder's point of view, in the seemingly vast landscape of the Nenets Autonomous Okrug (AO), Khanty-Mansi AO and Yamal-Nenets AO, Russia (Forbes et al. 2009; Stammler 2005 2011; Behnke et al. 2011; Kumpula et al. 2011). A few studies have shown that some of the industrial development indeed does interfere with existing migrations (Forbes et al. 2009; Anttonen et al. 2011; Kumpula et al. 2011). However, the availability of alternative terrain suitable for migration and the numerous requirements of a nomadic society remain unclear, including the possible competition from industry for high-value locations.

There is rising concern on how industrial development impacts herders and their communities in their traditional migrations and lives (Klokov 2000; Behnke et al. 2011; Kumpula et al. 2011). We examine here how infrastructure development in the Bovanenkovo industrial complex in the Yamal peninsula impacts traditional Nenets reindeer herders with regard to the following: (1) availability of migration routes and migration bottlenecks and (2) access to critical pasture areas and camp (chum) (Figure 1) sites in rugged terrain, during the migrations in 2008 to 2010.

\section{Study area}

The study was conducted in the Yamal peninsula, located in the Yamal-Nenets Autonomous Okrug (YNAO), in West Siberia, Russia. The peninsula is about $700 \mathrm{~km}$ long and $150 \mathrm{~km}$ wide. Yamal peninsula is characterized by an arctic plain, typically vegetated by dry, moist and wet graminoid tundra, interspersed with Betula sp. and predominantly Salix sp. communities (Forbes 1995; Forbes and Jeffries 1999). The area is a thermokarst arctic plain, with permafrost and cryogenic erosion, abundant with thaw lakes and polygons (Walker et al. 2009).

The area is crucial to the Nenets reindeer herders and their reindeer (Stammler and Wilson 2006; Forbes et al. 2009). According to official statistics, in the YNAO some 570,000 to 600,000 semi-domesticated reindeer are owned by over 14,500 nomadic people, including Nenets, Komi, Khanty and Selkup families (2010). Approximately 270,000 reindeer and about 1,000 fully nomadic households, comprising ca. 5,000 nomadic people, live on the Yamal peninsula (YNAO Statistics 2010).

Reindeer herding is organized in large enterprises, former sovkhozes - state managed agricultural farms. Each reindeer herding enterprise is composed of several brigades according to the number of the herds. Several herders are working together and migrating with their families all year around in a brigade. In addition, there are also a great number of private herders, which are also divided into units, to a certain extent comparable to the brigades. However, these private units are characterized by higher level of flexibility both in migration and social organisation. The private herders gather in larger units during insect infestations in mid-summer and split up in smaller family groups in late summer for the remaining year.

There is substantial diversity in herding traditions and migrations in the Yamal. Many Nenets herders begin their migrations from the wintering areas in the south in mid-late March. There is substantial variation concerning timing of the onset of migration, both for the individual units as well as among different brigades, with some starting both earlier and others later, dependent upon weather, total distance to summer pastures and dynamics and coordination with the migrations of other herders and the ecology of the reindeer (Dwyer and Istomin 2008; Istomin and Dwyer 2009, 2010). In early spring, in cold weather and favourable snow conditions for migration, Yamal herders can move up to $30 \mathrm{~km}$ on a good day, while later in summer, as snow melts, they typically move 4 to $7 \mathrm{~km}$ a day, sometimes as much as 10 to $12 \mathrm{~km}$, following the best route in the terrain for the sleds. Distances travelled each day depend on a range of conditions including, but not limited to, availability of pastures, weather, distance to other herds and ground conditions. 


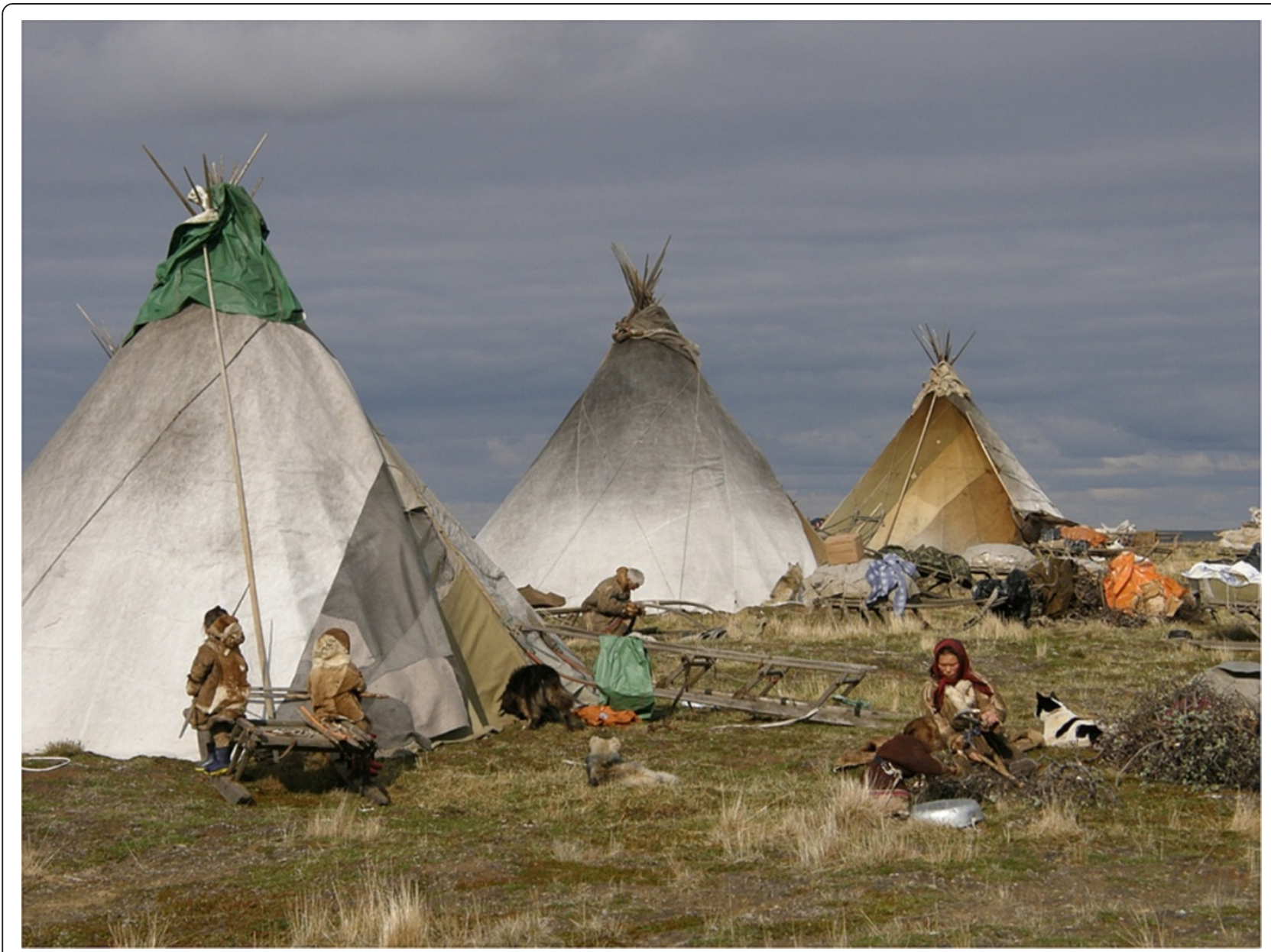

Figure 1 Traditional chum or tent camp site amongst Nenets pastoralists in the Yamal peninsula, Russia.

The industrial development commenced in the late 1980s, slowed down after the disintegration of the USSR and subsequent financial crisis during the mid-1990s in Russia and then increased substantially again in 2004 when the world prices for hydrocarbon rose (Forbes et al. 2009; Kumpula et al. 2011).

The area covering and surrounding the Bovanenkovo gas field was selected for a more detailed analysis. This included an area defined as the extended Bovanenkovo study area (Figure 2). In the extended area, 21 migration routes and approximately 15 reindeer herding units travel through the area during summer. Three reindeer herding units, composed of at least 100 men, women and children and ca. 9,800 reindeer (numbers varying annually), cross the Bovanenkovo gas field.

The Bovanenkovo industrial complex (BIC) is composed of an extensive infrastructure network consisting of roads, gas fields, living quarters, production facilities, power and pipelines, and gravel pits and quarries, creating substantial dust (Forbes 1995; Myers-Smith et al. 2006).

\section{Methods}

We investigated the study area at two levels: (1) The locations of 21 migration routes were provided by local Nenets reindeer herders and derived from official data from the Russian administration in Salekhard and YarSale, describing the large-scale migrations in the area. (2) At a more fine-scale level, one person followed reindeer herding units migrating through the BIC from 27 June to 26 August in 2008, and two persons followed two brigades from 1 July to 1 August in 2009. Migration routes, stops and camp sites were recorded using GPS or drawn on 1:100,000 topographic maps, along with the location of reindeer herders' crossing points of infrastructure and natural barriers. The names and numbers of brigades are anonymized for their protection throughout. 


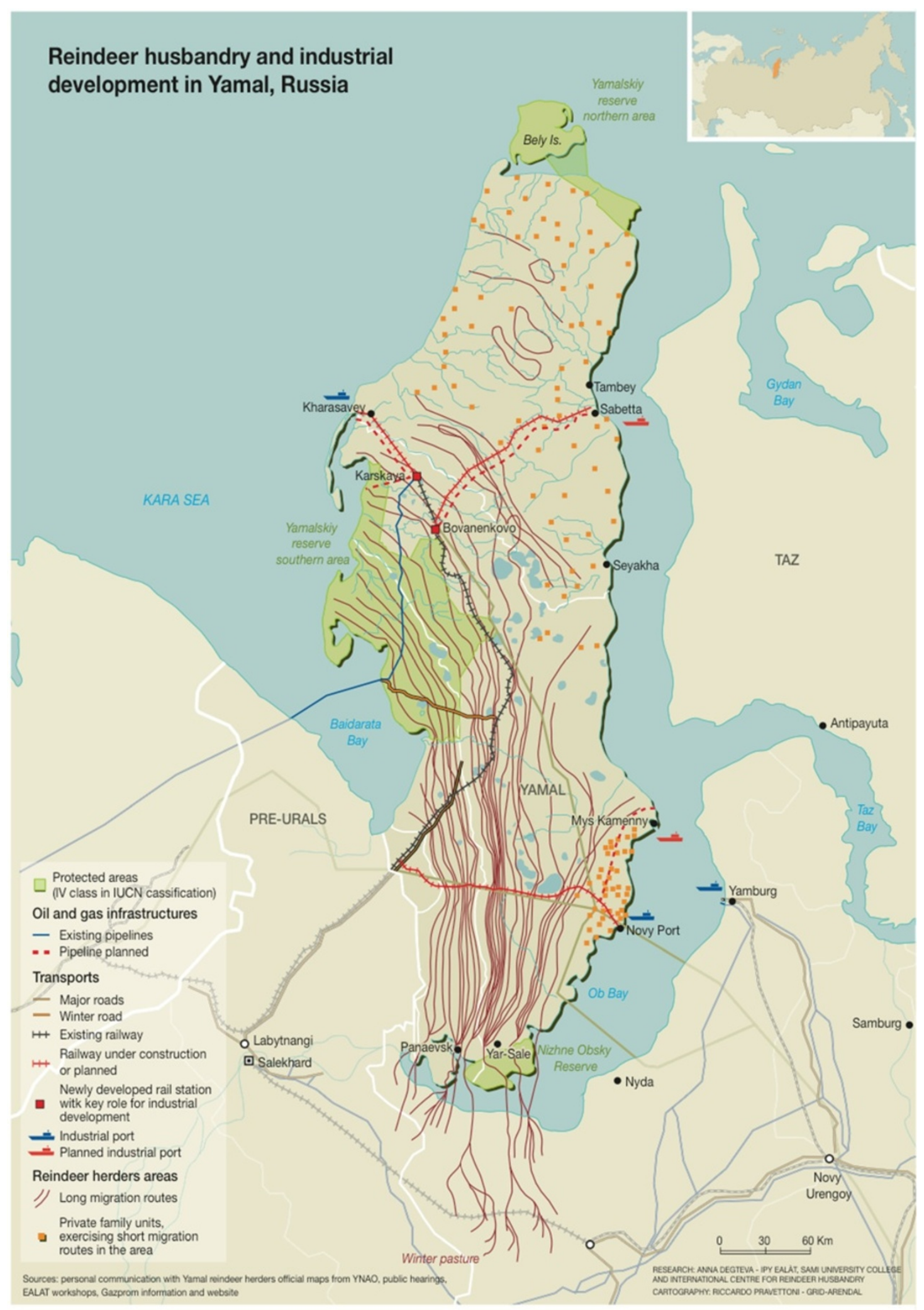

Figure 2 Major infrastructure and general migration routes of selected reindeer herding brigades and private units, Yamal peninsula. 
The distribution of gas extraction and transportation infrastructure was available from maps and two satellite image analyses (Oskal et al. 2010). LANDSAT satellite images were provided by Dr. Nancy G. Maynard of NASA Goddard Space Flight Centre, USA from 1987 to 2009 to map the gradual development of the Bovanenkovo industrial complex. For more updated information on infrastructure development, a comparison of various imagery and satellites has recently been produced (Kumpula et al. 2012). These data were not available to the authors during this study.

During 2008 to 2010, 91 interviews of 40 people were done among reindeer herders (18 people and 52 interviews), technicians and managers in reindeer herding enterprises ( 8 people and 22 interviews), NGOs ( 3 people and 3 interviews), industrial workers (5 people and 5 interviews) and government officials (6 people and 9 interviews), regarding the land use and management of the area. Herders were also asked about the impacts of BIC, as well as to draw migration routes on topographic maps (that they are familiar with) and record routes, camp sites and approximate dates of migration (Figure 3). Indepth conversations were also conducted on the traditional life, choice of routes and other aspects of their lives as reindeer herders. These conversations took place not as formal interviews, but rather as invitations to the herders to talk about their lives and challenges. This was done to allow the herders themselves to more freely communicate what they considered as important issues in their lives.

Information from herders was then cross-checked and compared with official maps and data and other land use representatives and for specific routes through and near the Bovanenkovo. Field records were based on map recordings and GPS to identify possible discrepancies, if any.

The distribution of rugged terrain (Nellemann and Thomsen 1994; Nellemann and Fry 1995), swamps and

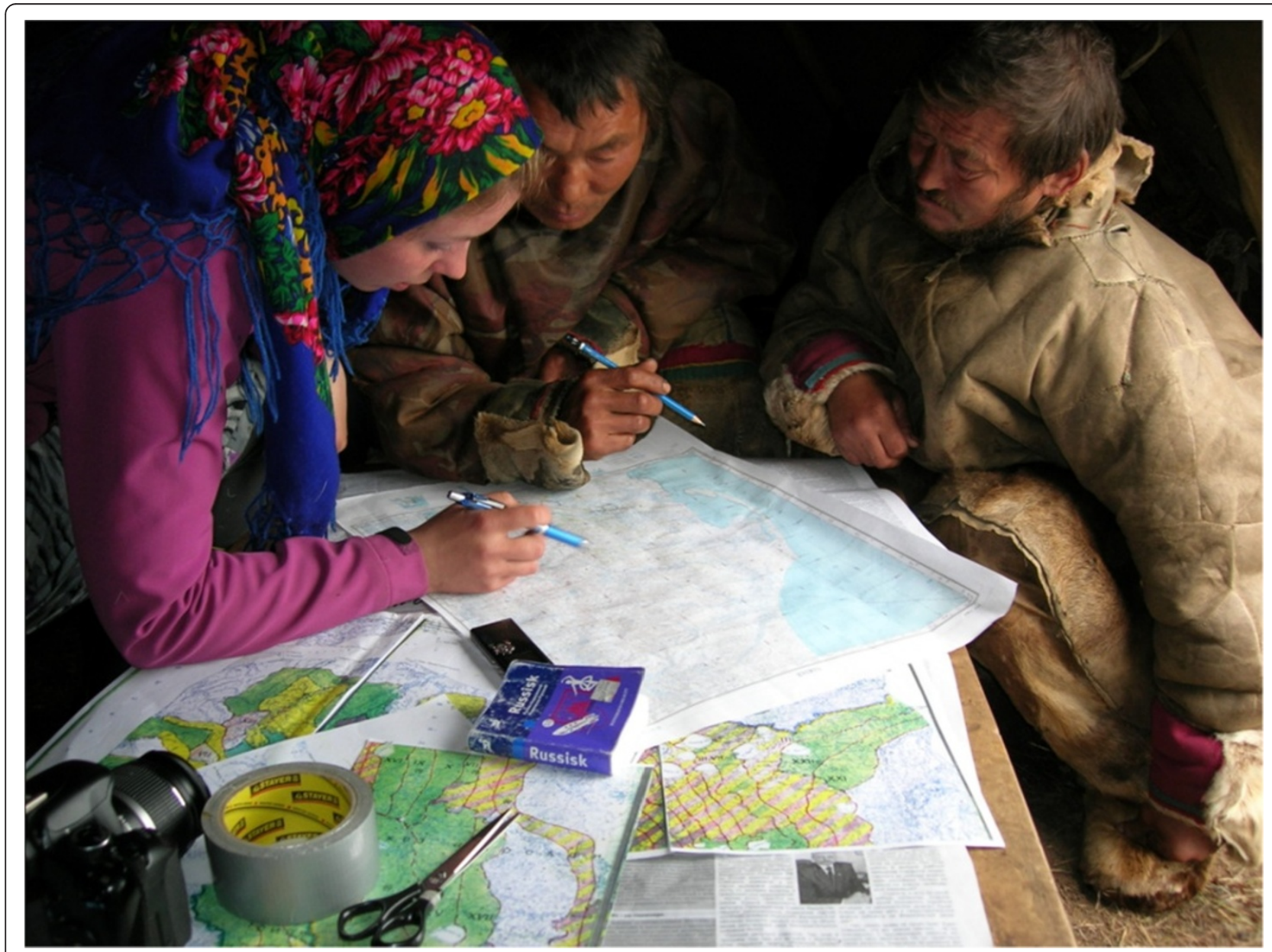

Figure 3 Nenets herders mark migration routes on topographic maps during the field work in Yamal, Russia. 
larger rivers are also major factors impacting herders, industrial developers and reindeer. Rugged terrain does not necessarily reflect steep or mountainous terrain, as the tundra plains are extremely flat, but reflect the undulating nature of the landscape where even slight undulations and changes in aspect have major effects on drainage and plant ecology. In the seemingly flat landscape of the Yamal peninsula, even slight differences in terrain of a few metres or even tens of centimetres can greatly influence drainage, vegetation and snow in winter, and hence plant phenology and forage conditions, as has been demonstrated on the flat North Slope coastal plain of Alaska (Nellemann and Thomsen 1994). Rugged or undulating terrain in an otherwise flat landscape firstly influences snowmelt, radiation and nutrient availability, and hence subsequently both vegetation distribution and plant phenology, which in terms affect reindeer grazing conditions (Nellemann and Thomsen 1994; Nellemann and Cameron 1998, 1996). Such terrain is also attractive to industrial developers as it comprises well-drained ground suitable for construction purposes (Nellemann and Cameron 1996). Rugged terrain is important to the herders for both travel and especially availability of dry camp sites and access to Salix sp. for firewood, an essential and critical resource in the everyday life of the herders. A unique feature of rugged terrain is that it supplies a wider range of resources - for herders and reindeer in different forms - within short horizontal distances.

We divided the entire study area into $2 \times 2 \mathrm{~km}$ grid cells on 1:100,000 scale topographic maps with a contour interval of $20 \mathrm{~m}$. The maps dated 1966 to 1987 also contained vegetation consisting of mainly willow (Salix sp.) communities and wetland tundra. The topographic maps were the only ones available to the authors at such detailed scale; topography and lakes matched well across borders on maps and images, even with decades in age between maps, reflecting slow changes even in an active thermokarst landscape. Here, terrain ruggedness indices (Nellemann and Thomsen 1994) were calculated on each grid cell. We also classified grid cells as having more or less than 25\% willow cover as derived from the maps. Currently, as a result of climate change, the tundra is 'greening' through the growth and widening of willow communities (Forbes et al. 2010; Macias-Fauria et al. 2012). Indeed, for our analysis here, the maps are only used as an indication for a very rough description of areas with a relatively high abundance of willows, as they are likely expanding across the tundra. As willow communities are considered important for both reindeer and herders, we analysed the distribution and use, as given by the presence of migration routes in 1-km-wide belts, of rugged terrain with $>25 \%$ occurrence of willows. We classified these grid cells further into developed (any infrastructure present) and undeveloped. We also registered all grid cells used for migration or camp sites. Chi-square analysis of rugged terrain was used to calculate use versus availability of different user categories.

\section{Results}

\section{Distribution of migration routes and industrial barriers}

The official migration routes of reindeer herding brigades were closely spaced from winter areas across the Ob Bay, running further from the southern part of the Yamal peninsula northwards approximately in parallel to the west and east coasts (Figure 2 ). The figure also shows routes of herding brigades in the northern part of the peninsula north from the Kharasavey River, the so-called Seyakha tundra, where migrations are shorter and often circulate. The same migration patterns are used by private herders; however, their migrations are not formalised by the official land tenure system. Figure 1 also shows the distribution of private reindeer herder units exercising very short migrations in Novy Port area and in Seyakha tundra. In total, Figure 2 covers the migration routes from 36 brigades and a substantial number of private reindeer units, giving a total of over 1,000 households of nomadic reindeer herders in the Yamal peninsula.

In general, in the western and southwestern part of Yamal, brigades and private units migrate mainly in parallel routes (with some diversity); however, the closest units also often have to maintain distance to other herders to avoid mixing different herds during grazing, when they follow the same routes, especially through bottlenecks in the terrain.

The number of river crossings and nedermas (migration road for the sledges) in rugged terrain or drier land is very limited, creating natural funnelling migration bottlenecks in the landscape, where many migration routes coincide (Figure 4). The units of private herders, who use exactly the same nedermas as the brigades and whose grazing areas interact very much with the brigades, therefore have to keep a distance in time or space (two to three weeks during green-up) in order to avoid mixing of herds and to allow for pastures to restore for grazing of the other herds.

Figure 4 also shows some of the ongoing and publicly available planned infrastructure development for the near future. These, in turn, will substantially increase the interferences of a large share of migration routes across the peninsula.

\section{Use and availability of rugged, elevated terrain by reindeer herders}

Land use was mapped in greater detail in the extended Bovanenkovo study area (Figure 4). Here, 21 migration 


\section{Reindeer herder migration routes and rugged terrain}

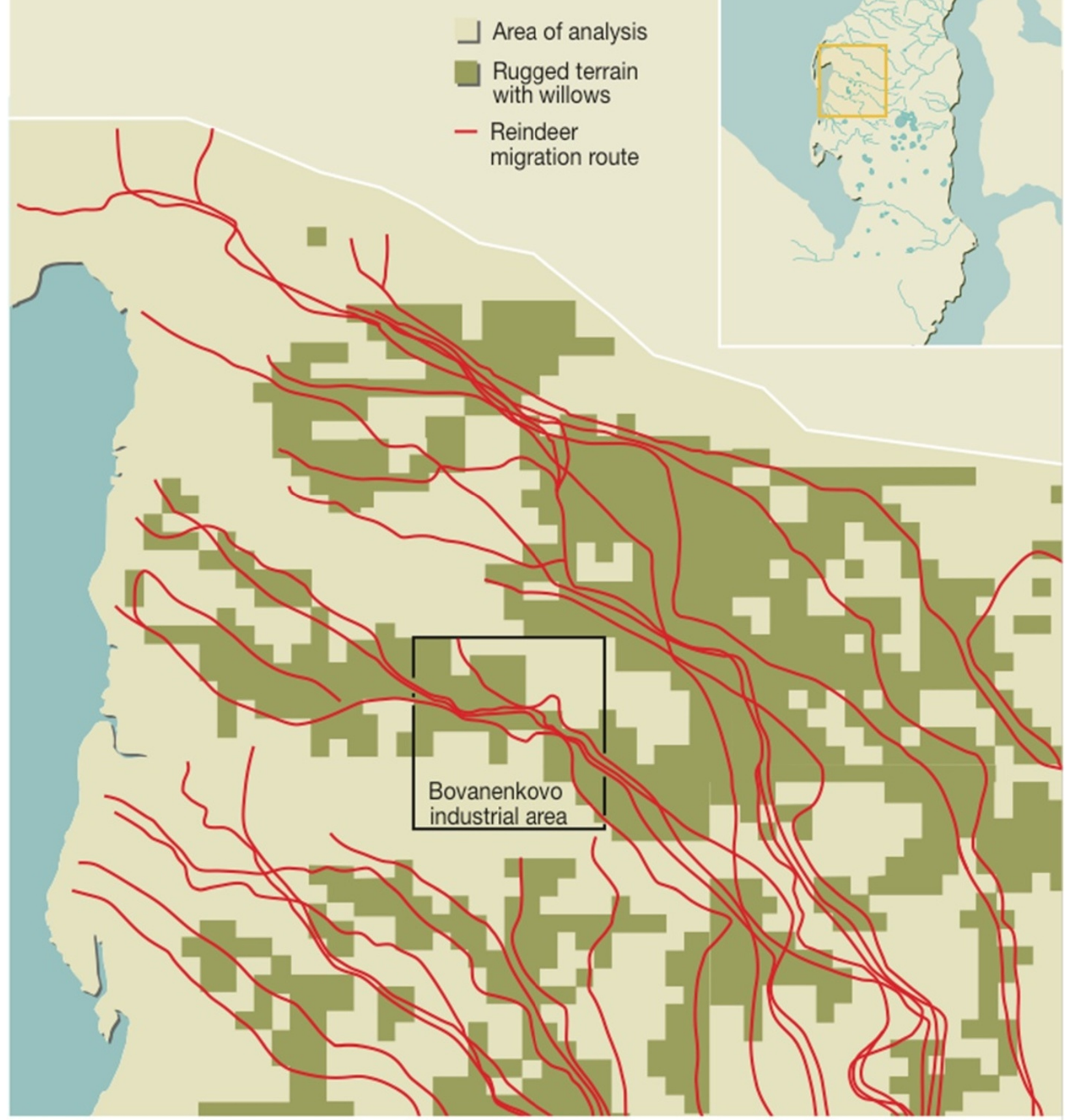

Figure 4 Distribution of reindeer herders' migration routes and rugged terrain in extended Bovanenkovo area. Notice the many 'bottlenecks', where natural funnelling terrain makes the migration routes coincide.

routes, currently exercised by 15 reindeer herding units, were identified and drawn on 1:100,000 topographic maps.
Rugged terrain with willows comprised $30 \%$ of the extended Bovanenkovo study area (745 out of 2,489 $2 \times 2$ $\mathrm{km}$ grid cells) (Figures 4 and 5). Of $1,780-\mathrm{km}^{2}$ recorded 


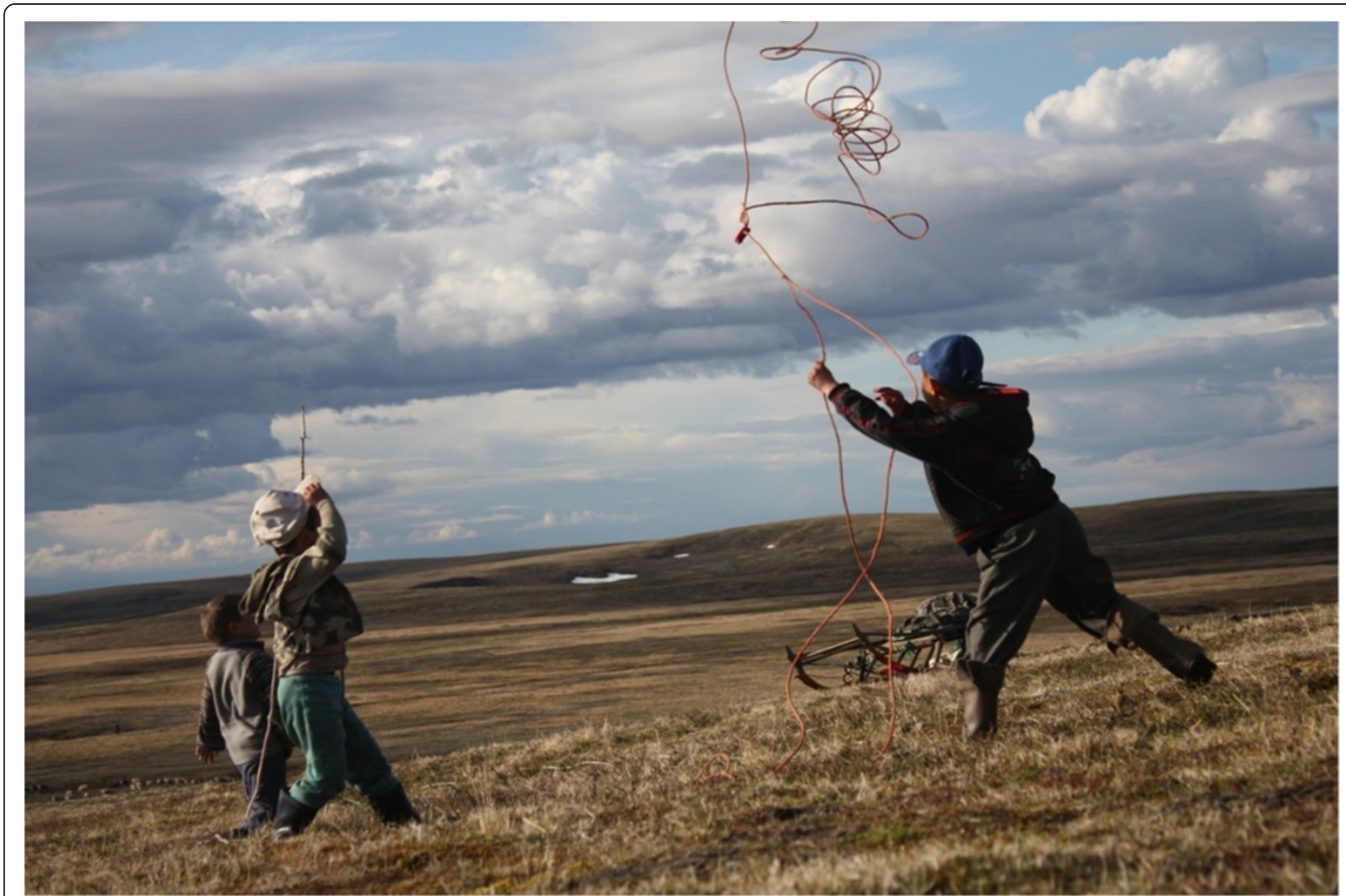

Figure $\mathbf{5}$ Children practising throwing lasso on hill. This type of rugged terrain is typical of Yamal, consisting of slender rolling of hills in an otherwise very flat landscape and of crucial importance to the herders.

grid cells with migration routes, $1,078 \mathrm{~km}^{2}$ was located in rugged terrain with willows (61\%), compared to a proportion suggested by availability of only $30 \%$. This proportion was greater than expected from that suggested by availability (30\% rugged terrain against $61 \%$ ) $(p<0.01)$. Of all rugged terrain with willows, $51 \%$ of the $2 \times 2 \mathrm{~km}$ grid cells had a migration route passing directly through.

Patch size and connectivity of patches influenced choice of migration routes (Figure 4). The selection of rugged terrain was even further evident at larger scales when observing use of larger clusters of rugged terrain with willows. Of the remaining $49 \%$ of rugged terrain with willows, only $1 \%$ (nine cells) was not part of a larger cluster of rugged terrain. Of individual patches with $>8 \mathrm{~km}^{2}$ ( $>2$ contiguous cells), absolutely all patches (100\%) were used for migration, although comprising <30\% of the study area.

The width or length of the patches also influenced their use for migration by creating bottlenecks for migration (Figure 4). In at least nine locations, $>3$ brigades had to use the same corridors to move from one patch to another, which are generally less than $4 \mathrm{~km}$ wide and sometimes as narrow as $1 \mathrm{~km}$ only, with the actual natural crossing point being much, much smaller. These corridors were up $20 \mathrm{~km}$ long. As is seen further below, these narrow corridors or 'bottlenecks' made the herders particularly sensitive to development of any infrastructure placement crossing or targeting such elevated terrain in the otherwise flat wet tundra.

\section{Changes in development (land use) 1987 to 2009 in the Bovanenkovo core study area}

Development of infrastructure increased substantially from 1987 to 2009 (Figure 6a,b). In 1987, only modest infrastructure was visible on the satellite images in comparison with the extensive network of pads, facilities, pipelines and roads by 2009. There are continually expanding activities of infrastructure in the fields of the Bovanenkovo group, such as towards Kharasavey and Kruzenshternskoe fields on the coast to the west and the northwest. This also includes introduction of new drilling rigs in BIC, a railway to Karskaya station and exploration activities in the area of Kruzanshternskoe fields, which had already occurred in 2010 to 2011. 

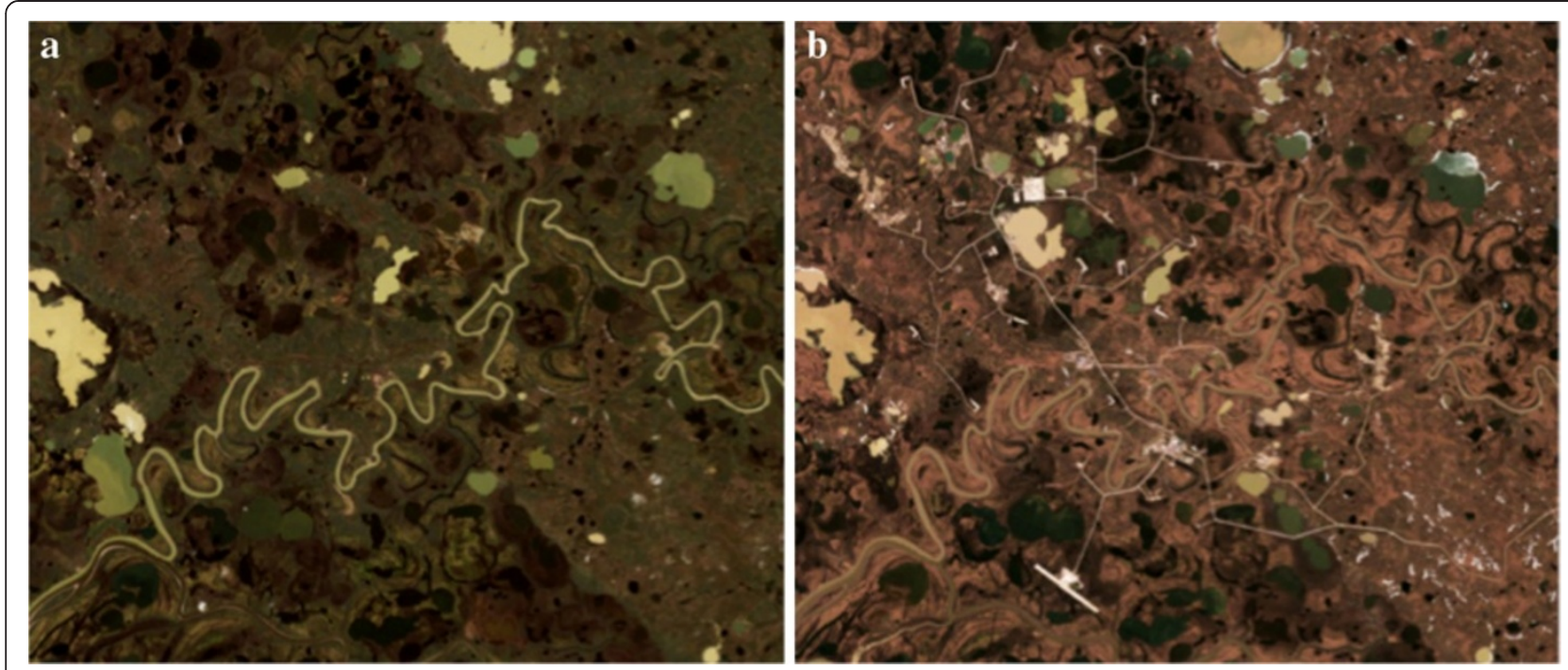

Figure 6 LANDSAT images of Bovanenkovo area from (a) 1987 and (b) 2009.

Inside the Bovanenkovo core area, infrastructure development interfered with the migration routes (Figure 7). Industrial development often targeted rugged, elevated drier land - which was used by herders for migration - for localizing infrastructure. The central Bovanenkovo industrial complex infrastructure crosses one long stretch of rugged terrain, at the narrowest less than a 2-km-wide bottleneck passage of rugged terrain where travelling with reindeer and sledges has traditionally been possible (Figures 4, 6a,b and 7). However, even within this narrow patch, only a few routes are physically possible (Figure 6).

In this area, four migration routes of two brigades and one private herding unit were used prior to the industrial development (Figure 7). However, after the industrial development took place, the two northernmost routes were physically blocked, and only the two rather close routes in the southern part of the Bovanenkovo industrial complex are still possible. Here, brigade 4 had to cross three roads in 2008 and one additional road in 2009, a total of four sand and paved roads, in addition to a major elevated site just at the crossing point of a pipeline.

Brigade no. ' $\mathrm{Y}$ ' had to cross four roads in 2009, again with pipelines. The same accounted for the private unit that lost their northernmost routes that were now physically impassable and in 2009 had, for the first time, to break the traditional land management system and migrate a few days prior to brigade ' $\mathrm{X}$ ', using the crossing points of brigade 4 and at the same time grazing at the pastures of brigade X (Figures 7 and 8; Additional file 1).

This was even more obvious inside the actual Bovanenkovo gas field. Here, for several critical passages on elevated land through wet marshes, several parallel pipelines and roads and even buildings were physically placed directly in the only possible narrow passages for migration across long stretches as much as approximately $21 \mathrm{~km}$, targeting the same limited drier land.

The former northernmost migration route had fewer stretches with crossing infrastructure. However, due to higher abundance of marshes and impassable wetlands, the options for migration were more limited. Indeed, this route was physically blocked by the placement of a plant and large quarry in one bottleneck, rendering the entire northernmost route useless. This route was normally used on the way from the summer pastures to the winter and sometimes towards the summer pastures by the private unit in particularly dry years where travelling was possible in this wetter terrain. This was opposed to the primary routes to the south where travel was possible in most conditions, but also here including some very narrow critical stretches.

Indeed, as much as 18 chum sites were lost, as well as at least one sacred site. A Nenets sacred place had been physically made into a major sand/quarry pit. While the offering/praying site itself had been marked by wooden pegs in a circle of $6 \mathrm{~m}$, the entire surrounding area had turned into an industrial excavation. From the point of view of the industrial workers, the sacred place was 'preserved', believing that this was limited to the actual offering/praying site; however, the herders felt that it was desecrated. Such sites are particularly sensitive, as there may be sacred hills, creeks or rocks far beyond that of an actual offering site. This is but one example of the very different perceptions of the landscape between the herders and modern society. The authors have noted many such similar examples in different parts of the world, including in North America and the Nordic 


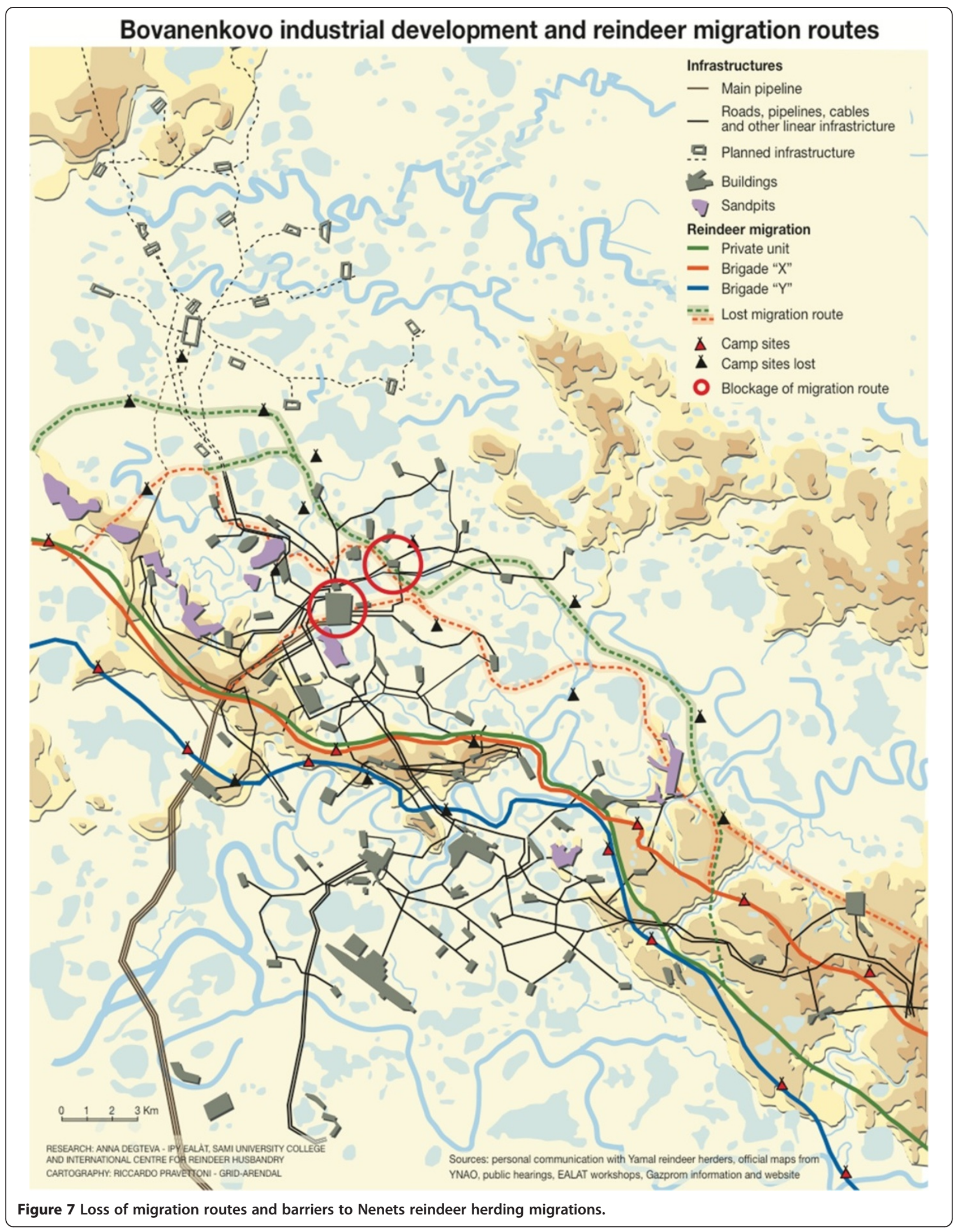




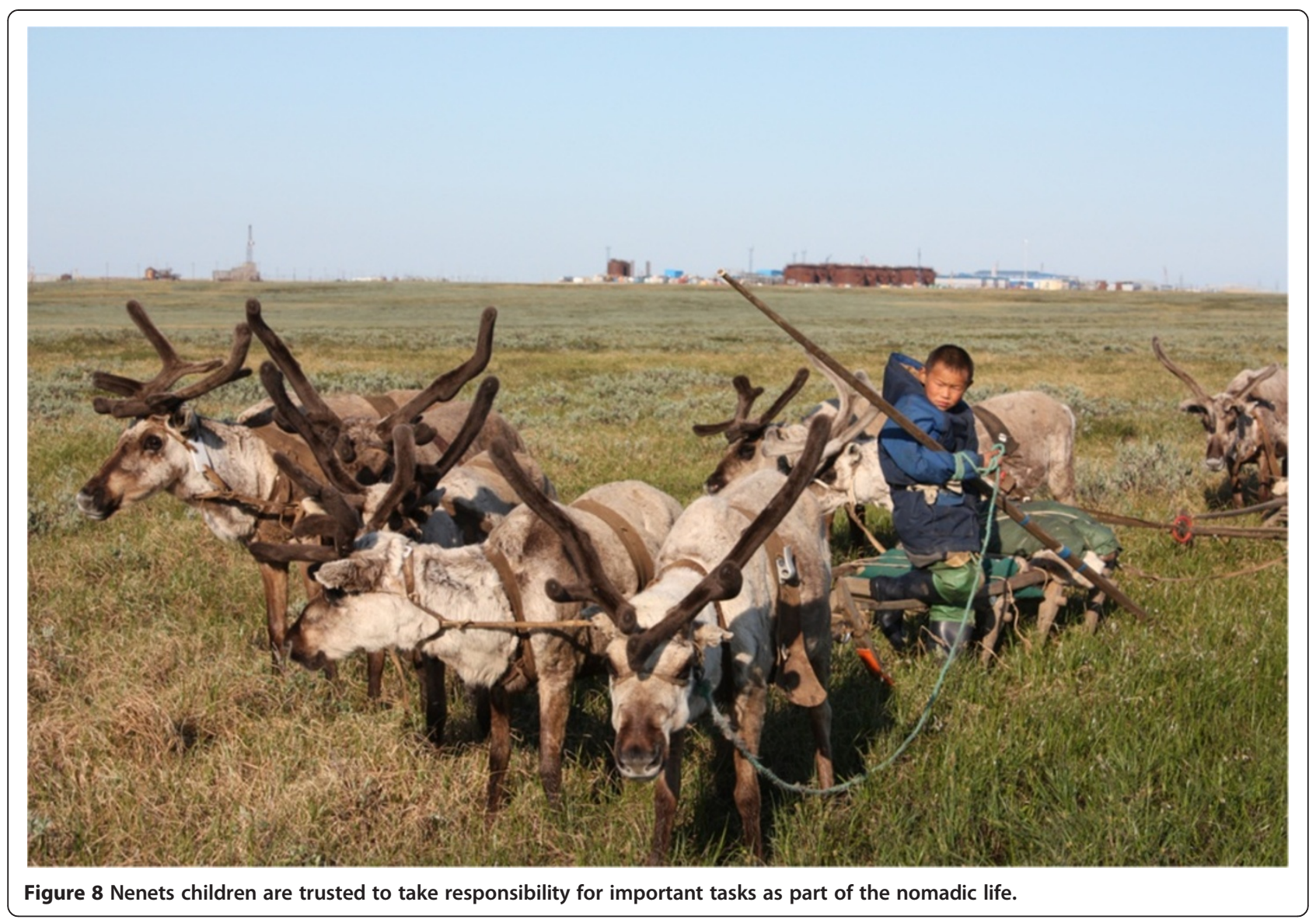

countries, where traditional indigenous sacred sites used to offer gifts in gratitude for the land and its blessings typically including an entire valley or calving ground are merely regarded by modern society as a site-specific localized spot, which is limited to where the offering was placed near a rock, similar to the physical limitations of a church yard or church. Traditional landowner views amongst Europeans and westerners - or in most urbanized societies - are contrasted by the spiritual relationship between the herders and the land incorporating much greater areas and a perception based on user right not land ownership - a concept among many traditional indigenous peoples which would be considered a sacrilege or impossible. Another factor is simply that the cognitive maps and understanding of the landscape may be very different between herders and the industrial planners (Istomin and Dwyer 2009). Increased dialogue here will be important (Stammler and Peskov 2008).

Hence, in sum, the established infrastructure complexes have created physical blockage of the herders' migration route, with the high abundance of infrastructure challenging herding through multiple crossings or long stretches with infrastructure parallel on narrow routes, causing risks that the reindeer will scatter. Furthermore, as most development sites and structures targeted the dry elevated rugged terrain for construction, this also resulted in the loss of possible corral places necessary for daily rounding up of reindeer, as well as for suitable chum sites (Figure 9).

\section{Discussion}

Reindeer husbandry in Yamal is still based on fully nomadic lives, as families of herders migrate by reindeer and sledges from one camp site to the next. This migration is neither random nor fully predetermined but is rather based on a holistic system of reindeer herding knowledge which incorporates a range of ecological, socio-economic and cultural considerations of the people in the landscape and implications for the wellbeing of the herders, envisioning the risks and opportunities from day to day (Istomin and Dwyer 2010; Behnke et al. 2011). Reindeer herders' mental modelling and perception of the landscape need to be better understood, although some aspects have been discussed elsewhere (Istomin and Dwyer 2010; Behnke et al. 2011).

The herders consider it crucial for the health of their reindeer to reach the coast of the Yamal peninsula after 


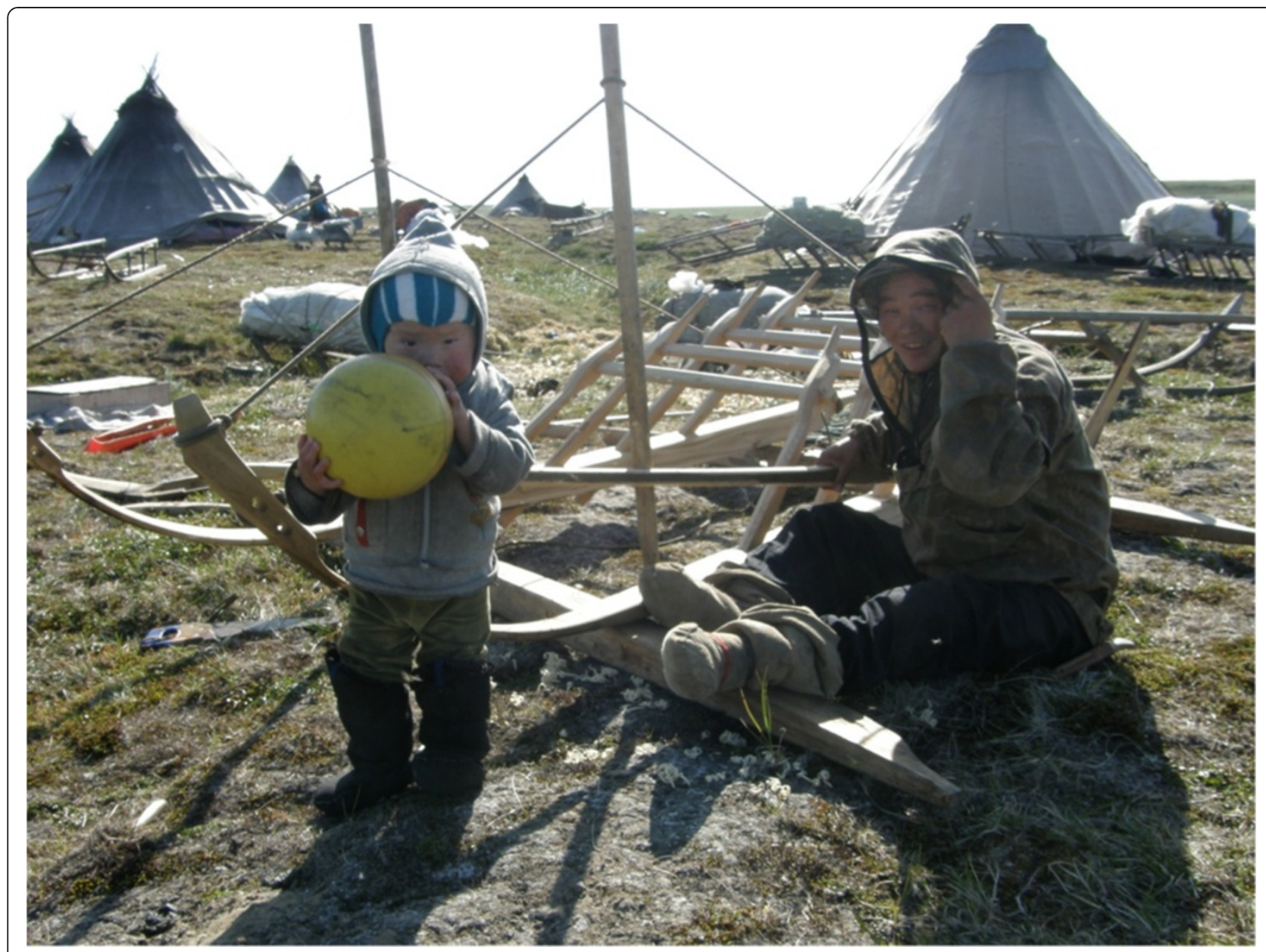

Figure 9 Nomadic family life is still preserved among the Nenets in Yamal, where children learn through observation and are included in every aspect of life.

their long migration from the winter pastures in the south (Figure 2). Herders claim that reindeer change behaviour and become 'more healthy' even within days upon reaching the coast (Andrey Serotetto, Khasova Pujko and Olga Khudi, personal communication), where they graze on a variety of plants, particularly in the $5-\mathrm{km}$ coastal zone. Coastal vegetation is usually abundant in salt and minerals and is known to influence quality of forage for both reindeer and geese (Staaland et al. 1983; Spaans and Postma 2001; Ngai and Jefferies 2004). Many coastal plants in the near-coastal zone of the Arctic have higher contents of many important minerals like phosphorous, magnesium, calcium and sodium, compared to inland forage plants like Carex aquatilis (Gadallah and Jefferies 1995; Ngai and Jefferies 2004). Animals require minerals as structural components of organs and tissues, as co-factors or activators in enzyme and hormone systems and as components in body fluids and tissues (Sharma et al. 2007). Re-supply of minerals to deficient animals may produce near-immediate responses in body vigour (Sharma et al. 2007). Access to coastal vegetation might therefore be crucial for reindeer also in Yamal.

Furthermore, the coast is also important for the reindeers' relief from insects during the mosquito and botfly (Oestridae) infestation periods from July to midAugust (Gerhart et al. 1996; Stammler 2005). Although reindeer in Yamal are managed and gathered during insect harassment, they cannot graze freely during the infestations, except during windy days or at the coast. Access to the coastal zone is therefore of major importance to both herders and reindeer alike, as the short period at the coast allows herders to rest and reindeer to graze without insect stress and subsequently restore body and fat reserves during summer (Gerhart et al. 1996). Hence, the turnaround at the coast provides an important part of the traditional way of herding, closely coinciding with the natural cycle and ecology of the reindeer (Stammler 2005; Dwyer and Istomin 2008). 


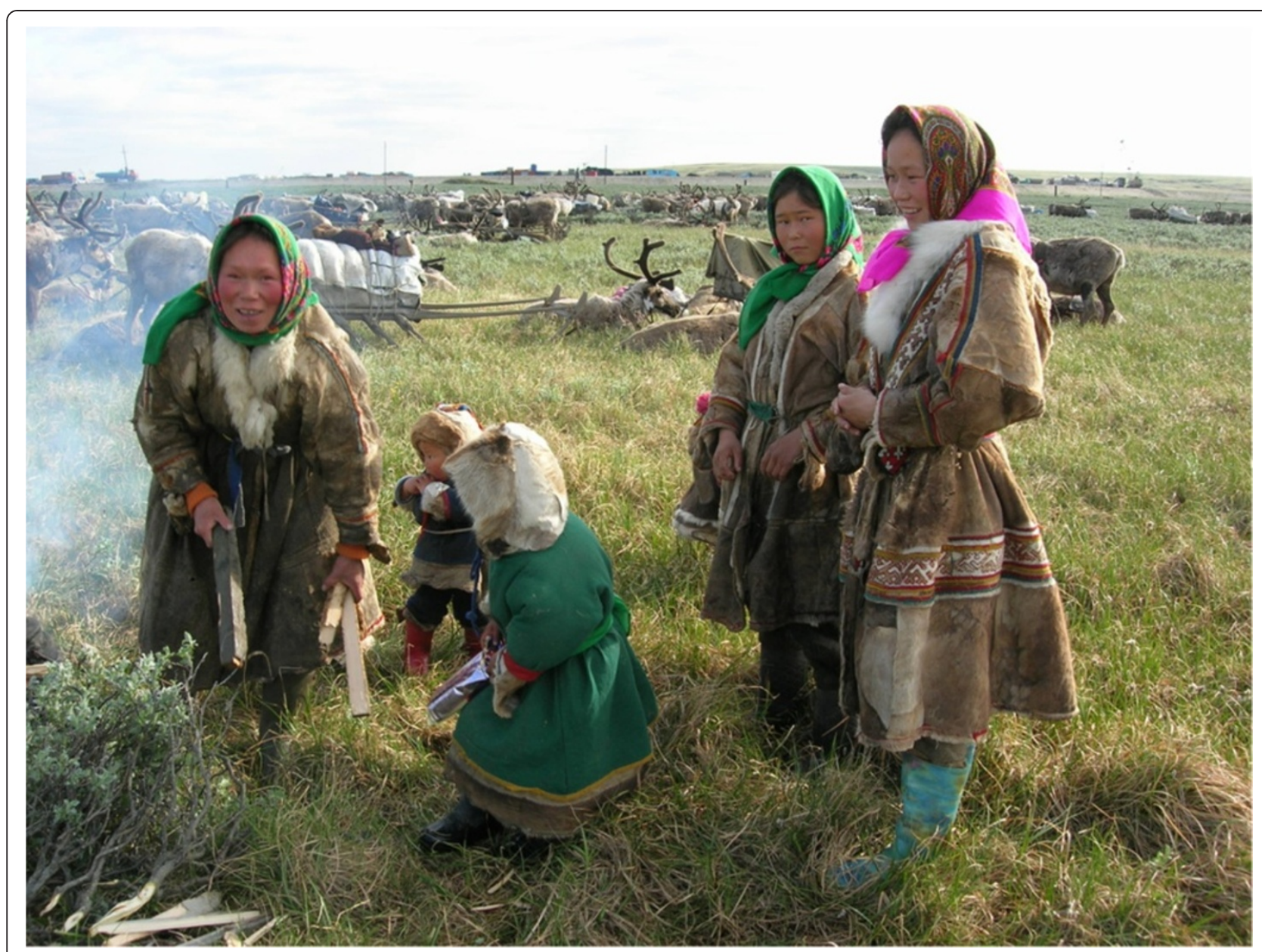

Figure 10 Women preparing a cooking fire from willows during a strenuous migration through the Bovanenkovo industrial complex.

\section{The role of rugged terrain for forage quality and insect relief}

Rugged terrain reflects a particularly rich resource for herders and reindeer alike. For reindeer and caribou, rugged terrain is characterized not only by greater forage biomass, which is a result of greater influx of sunlight on southerly exposed slopes, greater nutrient flows and micro-topographic diversity, hence enhanced conditions for plant growth (Nellemann and Thomsen 1994). Such terrain also provides greater variation in plant communities, snow melt, plant phenology and hence forage quality and diversity within short distances. Such terrain is used and selected extensively during calving in Canada and Norway (Nellemann and Cameron 1998, 1996; Vistnes and Nellemann 2001).

In Yamal peninsula, rugged terrain (Figure 4) also provides slight elevations making these areas more attractive as insect relief habitat, while smaller snow banks on the north side of very small bluffs make them attractive to reindeer for cooling and insect relief. This is also true for the flat areas in between, with permafrost coming as close to the surface as 15 to $20 \mathrm{~cm}$ in Yamal, providing cooling areas for reindeer in warm days. In the summer, the lower-lying rich nutritious pastures are used in the cool weather, while the dry elevated areas, preferably lichen-free and located close to the camp sites, are needed in hot weather during insect harassment, as the herd is running in circles as a protection. The herd may even approach human infrastructure in the search of insect relief (Skarin et al. 2004). Likewise in Yamal, herders may provide protection for the reindeer against insects by making smoke screens or spraying modern chemicals.

The pasture quality, as viewed by the reindeer herders, is therefore not simply measured by standing biomass, plant phenology or carrying capacity, but valuable pastures also provide a wide range of alternative range qualities in order for reindeer and herders to respond to different weather and social conditions - a variety typical 


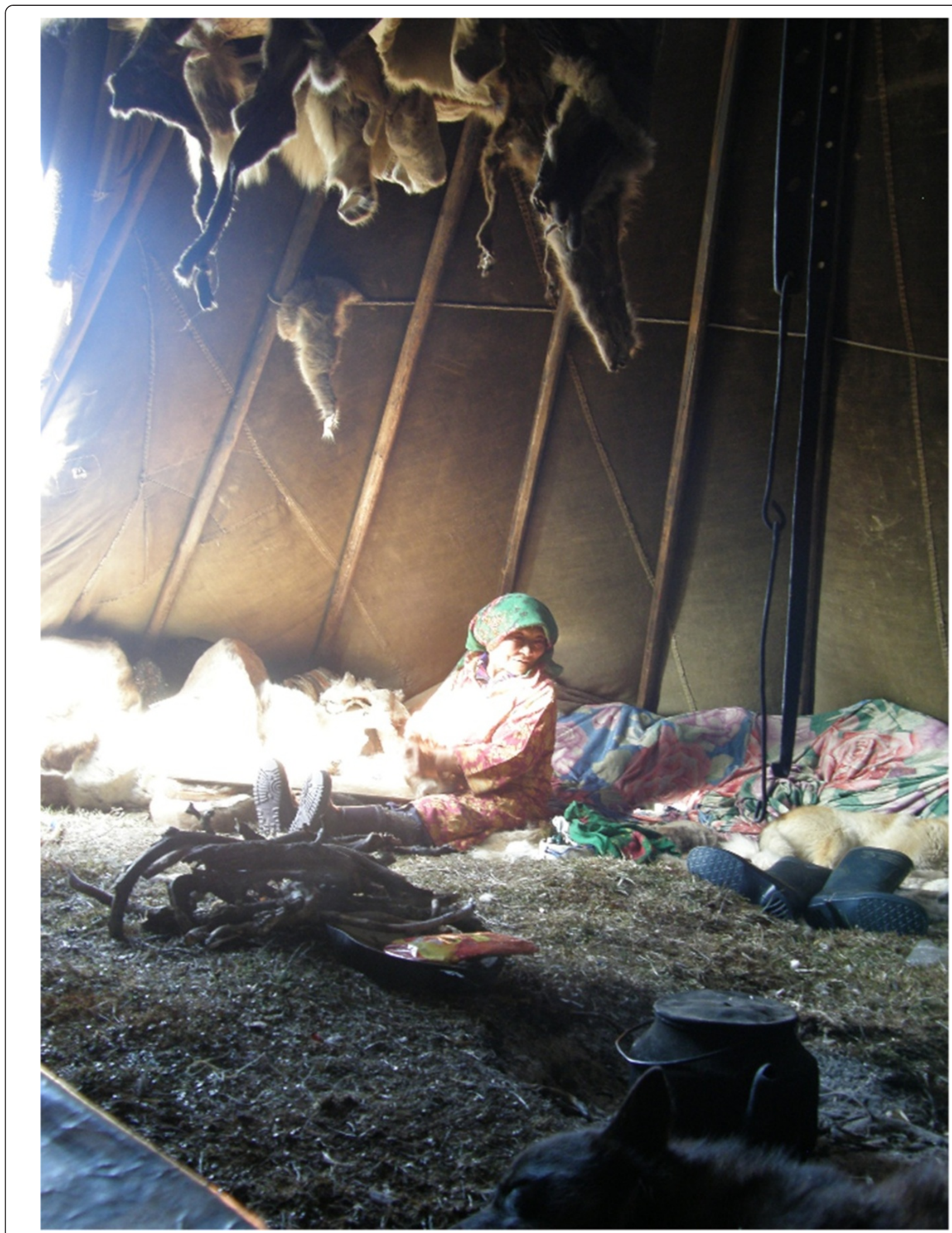

Figure 11 Woman doing her chores inside a tent on an elevated camp site. This is so typical of the 'rugged' terrain. 


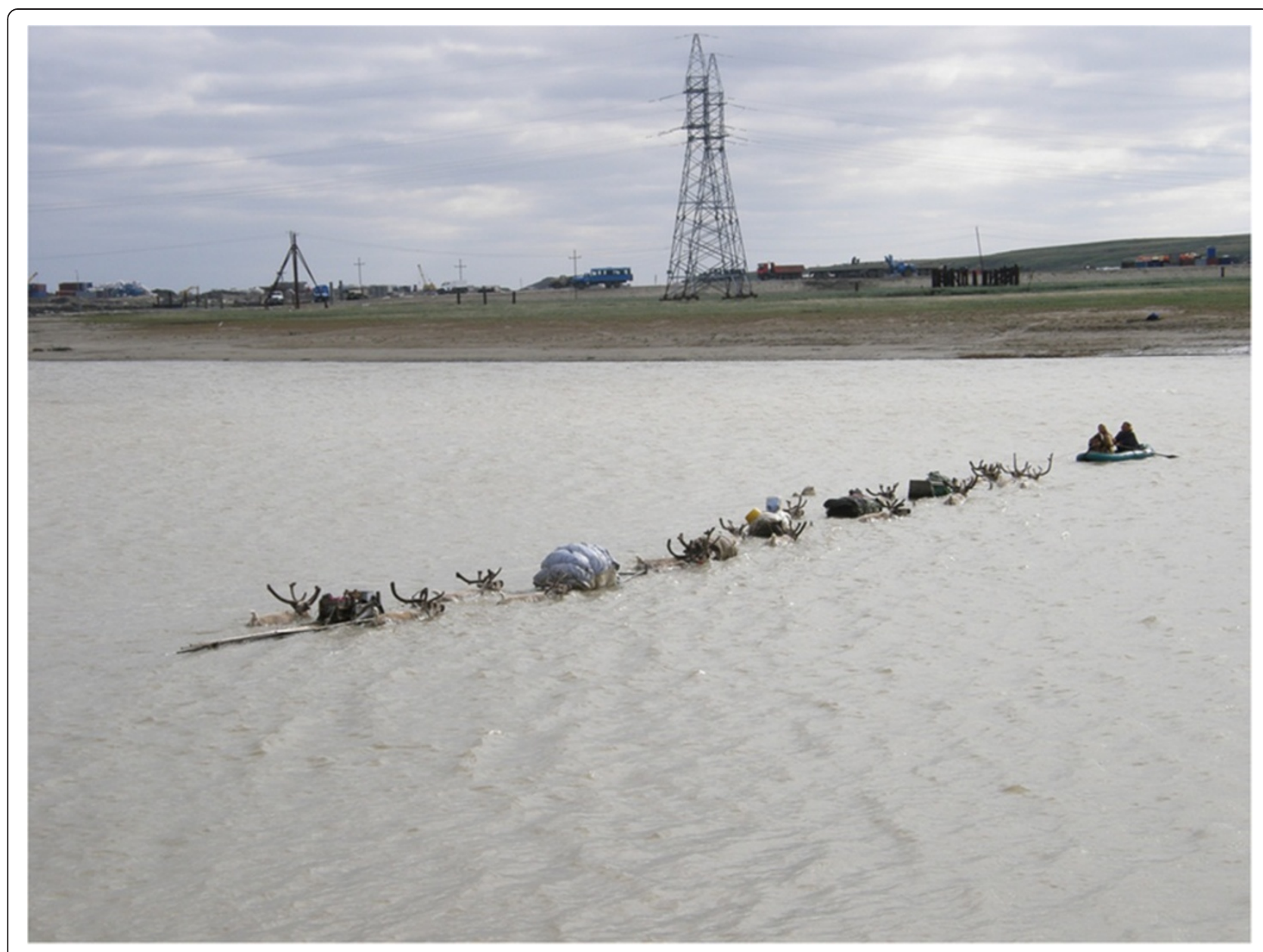

Figure 12 Crossing rivers is highly demanding for the reindeer herders.

of rugged terrain. The 'good' summer pastures provide enough water for the people and animals in the years of dry summers with low precipitation and also an opportunity for people to travel by sledges through the landscape during the unusual extremely rainy summers. The cluster of rugged terrain located northwest of the Bovanenkovo industrial complex is particularly valuable to both reindeer and herders alike due to the diversity of assets such as insect relief, availability of migration routes in different weather, camp sites and plant diversity.

All of these aspects of the slightly rugged terrain in an otherwise flat landscape are deeply appreciated by the herders and in their selection of stopping points along the migration, and when they move the herds around to graze from the camp sites.

\section{The role of rugged terrain for migrations to the coast} In spite of the seemingly vast undeveloped landscape, virtually all parts of the Yamal peninsula are used for reindeer migrations. The migration routes illustrated here (Figures 2, 4 and 7) only represent a portion of those present, but nonetheless comprise a dense, closely delineated system of migration routes and an intrinsic advanced system of avoiding mixing with other herds while still finding terrain passable and suitable for migration. Indeed, as was evident in the extended as well as the core Bovanenkovo area, there were a highly limited number of suitable passages for herds of reindeer. While the area seemingly is vast, there are few corridors suitable for reindeer herders' migrations. The traditional nedermas - Nenets migration trails - connect and run through all of these patches of rugged terrain, enabling them to access camp sites with all their requirements, corral sites and good grazing areas on their way to the coast.

Indeed, pulling sledges with all camp equipment across the tundra in summer results in high friction on the ground. This is particularly difficult in dry weather and when the reindeer are weak following a long migration 


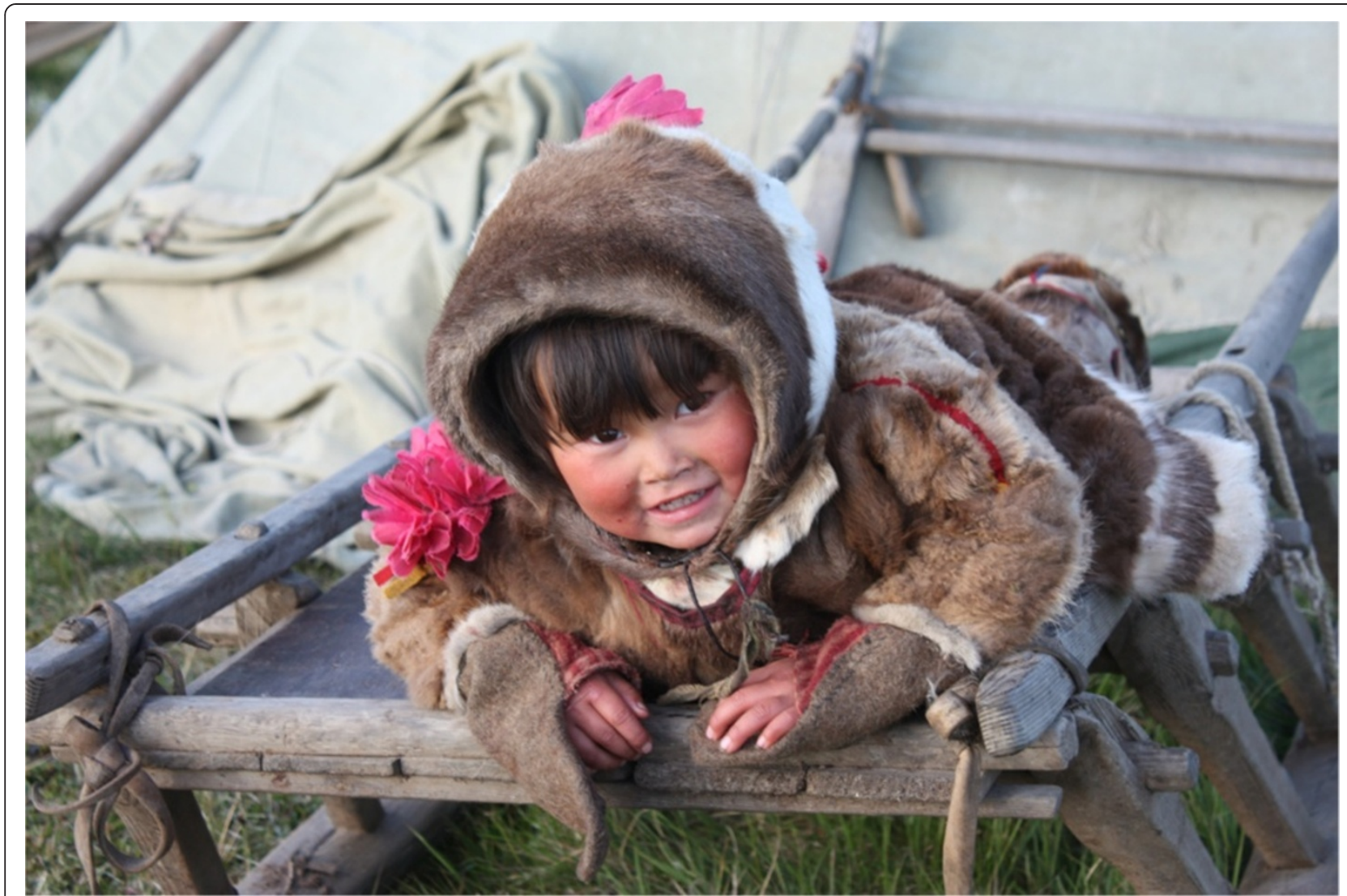

Figure 13 A Nenets child playing on a sled in a chum or camp site on elevated ground.

and winter; selection of less strenuous routes therefore becomes very important for both the herders and their reindeer.

The natural features of the local landscape are also considered and used by herders in their daily management. For instance, the rivers may also help as natural borders in managing the herd. Rugged terrain also provides a greater abundance of camp sites.

\section{Use of rugged terrain for camp sites}

The elevated sites so typical of rugged terrain (Figure 2) in an otherwise very flat landscape also provide a good focal point for herders moving the reindeer herd anything from a few hundred metres up to $6 \mathrm{~km}$ away, thus avoiding both trampling and overgrazing near chum sites. The drier ground is also very important as herders may have to corral or round up the herd up to several times and keep them close to camp. In lowlying terrain, erosion and trampling during corral activities would become a serious problem. Indeed, on the eastern part of the Yamal peninsula, some brigades have to migrate almost every day because chum sites would turn into mud and swamp after one or two corral activities.
The sites also offer a greater abundance of willows, facilitating collection of firewood for cooking purposes so crucial in camp life (Figures 10 and 11). The rugged terrain also provides better cover for women and others for discreetly conducting their natural requirements. Finally, rugged terrain provides excellent ground for the children to explore and play in, unlike the wetter low-lying flats so dominant in the tundra (Figure 12). It is well established among herders that while routes may change slightly according to range and herding conditions in one year, certain camp sites are denoted as 'happy', and thus particularly important to reach, as an important part of nomadic life. Aspects of this could include particularly popular children's playgrounds (Svoboda et al. 2011) (Figure 13), which are also important for the entire families (Figure 14).

Hence, the rugged terrain provides a range of opportunities enabling the herders to cope with changing conditions in weather, ranges or social issues by providing more resources and a greater diversity in range characteristics, alternative migration corridors, availability of camp sites, access to fire wood and much more within short horizontal distances. The rugged terrain - limited in extent on the coastal plain - provides a very important 


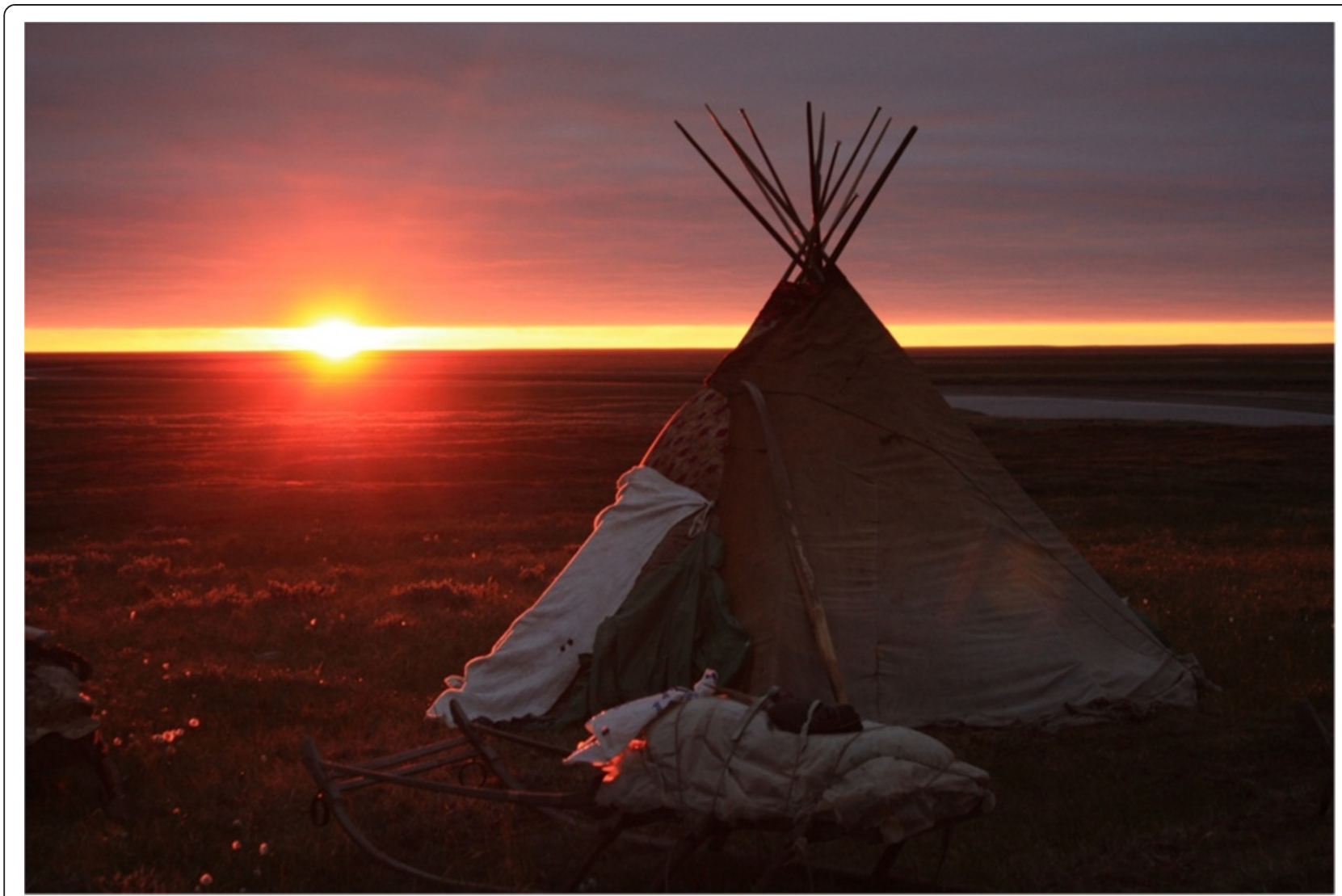

Figure 14 Sunset at a camp site on a hill in 'rugged' terrain.

resource to the herders by improving the quality of life and facilitating herding practices.

\section{Impacts and competition for land by industrial development}

Development of infrastructure has broad impacts on the Nenets by typically targeting well-drained ground, so characteristic of parts of the rugged terrain, including crucial bottlenecks for migration. Natural funnelling terrain, called bottlenecks here, forms landscape corridors typically surrounded by low-lying wet marshes less suitable for travel (except in the driest of years) and are crucial parts of the reindeer migration routes. Such competition for critical terrain features is also found elsewhere, for example the Prudhoe Bay - Kuparuk oil field in Alaska in relation to calving grounds for the Central Arctic caribou herd (Nellemann and Cameron 1998, 1996). While the actual surface footprint of the development may appear very small, usually a few percent, such development has been shown in many instances to impact wild animals or herding systems far beyond the footprint by generating avoidance, reducing access to insect relief habitat or to areas with high forage availability or even to have an impact on calf survival (Vistnes and Nellemann 2009). Herders have to cross not only the infrastructure, but also rivers in the industrial complex (Additional file 2).

Many of the impacts known about wild reindeer have been recorded in the semi-domesticated as well (Vistnes and Nellemann 2009; Anttonen et al. 2011). With the current density of BIC infrastructure, herder families are still able to migrate through the complex. However, the development limits their choice of migration routes and adaptation to different herding and weather conditions as well as restricting access to traditional resource-rich camp sites, fishing sites and other valuable assets (Forbes et al. 2009; Kumpula et al. 2011) (Figure 15).

Herders also called the area west and northwest of the Bovanenkovo field the 'Green peninsula', meaning that the particularly good pasture land could only be accessed through the migration passages but which might become bottlenecks due to industrial development, since the surrounding wet areas are too wet for access. Once again, these natural funnelling passages for migration are of major importance for the herders.

The islands of rugged terrain on the Yamal tundra are also valuable during autumn, where the ridges and bluffs provide lichens for the reindeer, and herders often try to limit grazing on these sites in spring so as to protect them for the autumn migration. In particular, the area 


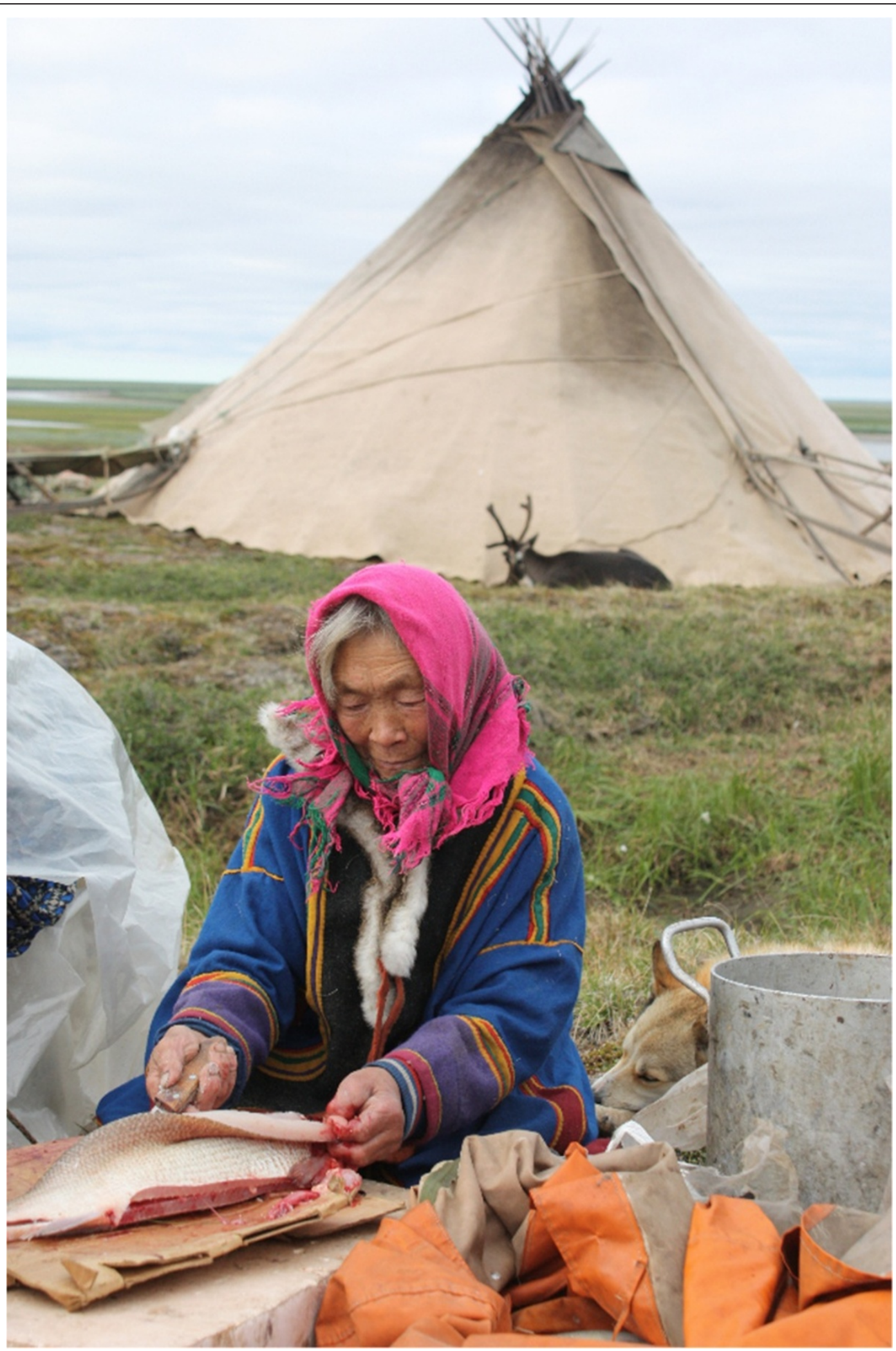

Figure 15 Nenets woman cleaning fish, an important food source during migration for the pastoralists. 


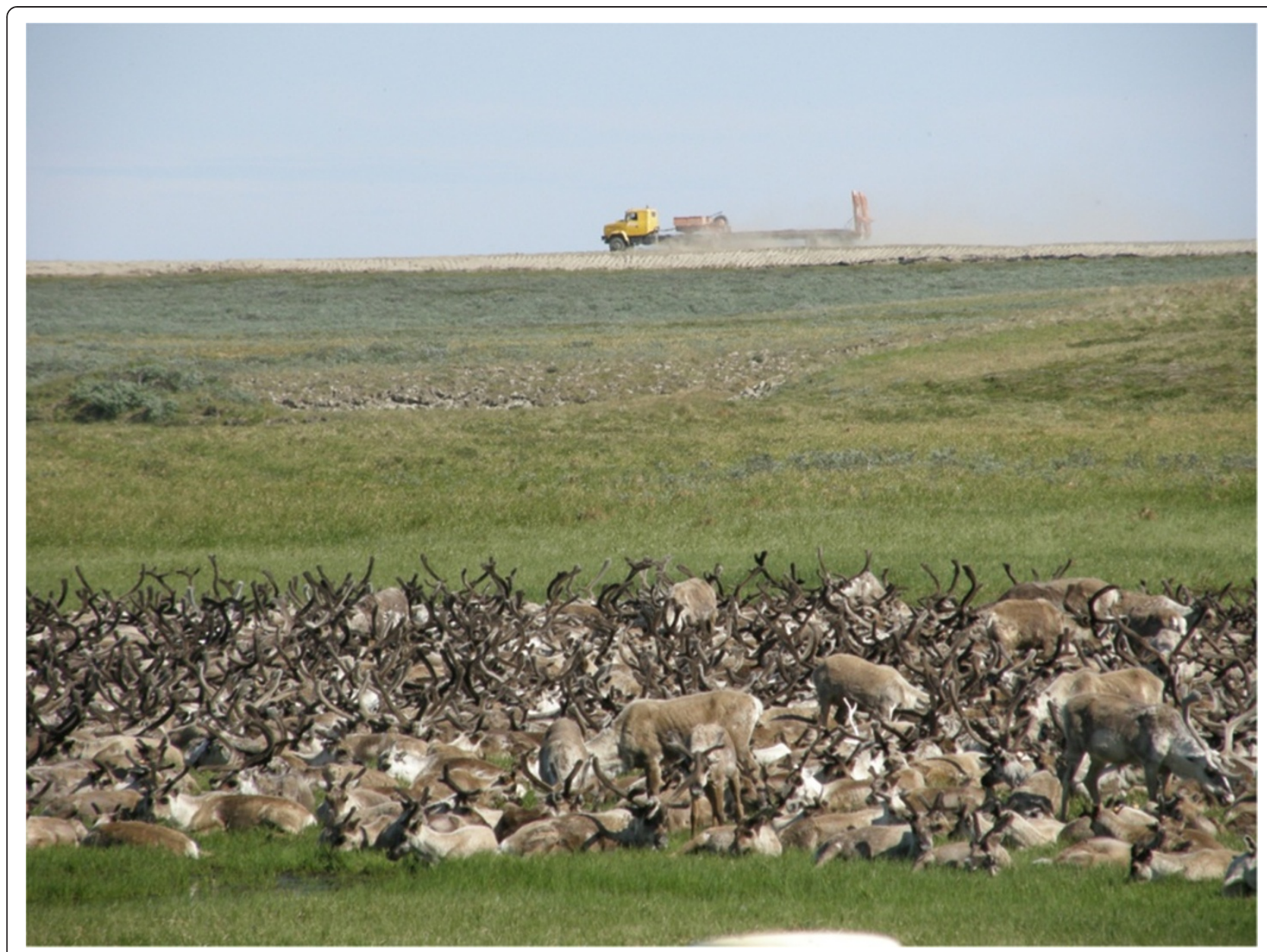

Figure 16 Dust from a truck along an elevated ridge near the industrial complex, while reindeer have been gathered further down. Herders dislike the dust that can carry far with the wind and creates a feeling of a dirty environment.

allocated for BIC used to be very valuable for the herders of brigade $\mathrm{X}$ during early autumn grazing (end of August), as the elevated grounds provide abundance of lichens. These ridges are no longer accessible to any of the brigades or the private herders due to industrial infrastructure on the very same elevated terrain features (Nellemann and Cameron 1998, 1996).

There is also a substantial social impact on the herders beyond their reduced access to traditional camp sites and sacred sites; other impacts include changes in migration patterns, disruption or increased speed of movement, as well as invariable interactions and disturbance by industrial workers, pollution, dust and competition for fisheries (Kumpula et al. 2011; Behnke et al. 2011). The extensive dust, for example, generated by road traffic and the many gravel pits, is believed by the herders to be unhealthy for the reindeer while affecting drinking water, clothing and all the vegetation. Collecting firewood with dust, dust on the forage or any plants gathered or on clothes, creates a feeling among the herders of a dirty and unhealthy environment (Figure 16). There is also concern over the fact that changes in the hydrology of lakes and rivers with development, along with competition from industrial workers, may impact the fisheries (Kumpula et al. 2011). Hence, the overall quality of the area as a natural resource base for the herders is compromised or diminished by industrial development.

In the near future the impact of BIC on the reindeer herders is projected to increase, as the development will intensify with more drilling pads, construction of connecting pipelines, the railway extended towards the gas field and port of Kharasavey, and the proposed port at Sabetta (Figure 2).

\section{Conclusions}

Our results ostensibly show that even apparently minor industrial development in a seemingly vast and generally flat landscape like the Yamal peninsula may directly affect the availability of critical migration passages in the landscape, creating bottlenecks for the nomadic 
herders. Furthermore, industrial development targets the same crucial rugged and elevated terrain that is so valuable to reindeer herders and their animals. The physical footprint of Bovanenkovo installations is small, but for the three herding units migrating through these bottlenecks, the industrial development resulted in blockage of two out of four possible routes, loss of major grazing areas and subsequent loss of access to at least 18 traditional camp sites and one sacred site along their traditional route. Herders and their livestock actively select and follow these patches of rugged and elevated terrain that are scattered across the landscape. Industrial development may subsequently directly interfere with the accessibility of such terrain during migration and the associated land use by Nenets herders and may even jeopardize entire migration systems or delay their timing by blocking traditionally used migration corridors. The industrial development also interferes with the herders' quality of life by not only impacting their migratory cycles, but also the resources available to them in the landscape. As climate change is also rapidly accelerating in the Arctic, continued industrial development will further compromise the ability of the herders to adapt. Indeed, an early break-up of rivers further south in the early stages of migration could either hinder or delay migrations and herders' ability to reach the coast in a timely fashion. Continued industrial development will threaten the cycles of herding even more and reduce the options available to herders, in spite of the will and knowledge of these people to adapt to changing conditions.

\section{Additional files}

Additional file 1: Reindeer herders crossing Bovanenkovo industrial complex and roads with their reindeer during migration.

Additional file 2: Nenets migrations and crossing of river in

Bovanenkovo industrial complex, Yamal, Russia.

\section{Competing interests}

The authors declare they have no competing interests.

\section{Authors' contributions}

AD conducted interviews in the field, analysis and writing and $C N$ provided guidance, analysis and writing. Both authors authors read and approved the final manuscript.

\footnotetext{
Acknowledgements

The project is a part of IPY EALAT-RESEARCH: Reindeer Herders Vulnerability Network Study: Reindeer pastoralism in a changing climate, supported by Research Council of Norway grant number 176078/S30. We would like to thank Nenets reindeer herders in Yamal-Nenets AO for sharing their knowledge and information about nomadic use of the Yamal landscape. Very special appreciation to Prof. Svein D. Mathiesen for support in the field work in Yamal. A thanks also to reindeer herders Nyadma Khudi, Nina Khudi and Khasova Pujko, Igor Slepushkin, Andrey Serotetto and Konstantin Oschepkov for their valuable assistance. Special thanks also to the local people in the villages of YarSale and Seyakha and in the city of Salekhard for sharing knowledge and hosting researchers. Dr. Nancy Maynard and Mr. Alvaro Ivanoff at NASA
}

Goddard Space Flight Centre, Washington DC, USA are acknowledged for providing the LANDSAT images from July 1987 to 2009 from the research area of Yamal. A special thanks also to Riccardo Pravettoni at UNEP GRID Arendal for unique assistance with graphics. Thank you also to Professor Konstantin Klokov, St. Petersburg State University for assistance and support. We also thank Philip Burgess for making comments on an early draft version of the article. Photos were taken by Anna Degteva and Svein D. Mathiesen. Videos courtesy of Mathiesen and edits by P. Burgess.

\section{Author details}

${ }^{1}$ St. Petersburg State University, St. Petersburg 199034, Russia. ${ }^{2}$ Sami University College, Kautokeino 9520, Norway. ${ }^{3}$ UArctic EALAT Institute at International Centre for Reindeer Husbandry, P.O. Box 109, Guovdageaidnu/ Kautokeino 9521, Norway. ${ }^{4}$ United Nations Environment Programme/ GRID-Arendal, Lillehammer 2624, Norway.

Received: 6 March 2013 Accepted: 4 June 2013

Published: 7 August 2013

\section{References}

AMAP. 2008. Arctic oil and gas 2007. Arctic monitoring and assessment programme. http://www.amap.no/oga. Accessed 15 August 2011.

Anttonen, M, J Kumpula, and A Colpaert. 2011. Range selection by semidomesticated reindeer (Rangifer tarandus tarandus) in relation to infrastructure and human activity in boreal forest environment. Arctic 64: 1-14.

Behnke, RH, ME Fernandez-Gimenez, MD Turner, and F Stammler. 2011. Pastoral migration: Mobile systems of animal husbandry. In Animal migration: A synthesis, ed. EJ Milner-Gulland, JM Fryxell, and ARE Sinclair, 144-171. Oxford: University Press.

Cameron, RD, WG Smith, RG White, and B Griffith. 2005. Central Arctic caribou and petroleum development: Distributional, nutritional, and reproductive implications. Arctic 58: 1-9.

Dwyer, MJ, and KV Istomin. 2008. Theories of nomadic movement: A new theoretical approach for understanding the movement decisions of Nenets and Komi reindeer herders. Hum Ecol 38: 521-533.

Federova, NV. 2003. Каслание длиной в две тысячи лет: человек и олень на севере Западной Сибири. (Migration lasting for 2000 years: A human being and a reindeer in the north of the West Siberia.) Yamal Archeologigal Expedition. http://yamalarchaeology.ru/index.php? module=subjectsandfunc=viewpageandpageid=84. Accessed 16 March 2011.

Forbes, BC. 1995. Tundra disturbance studies. 3. Short-term effects of aeolian sand and dust, Yamal region, northwest Siberia, Russia. Environ Conserv 22: 335-344.

Forbes, BC, and RL Jefferies. 1999. Re-vegetation of disturbed arctic sites: Constraints and applications. Biol Conserv 88: 15-24.

Forbes, BL. 1999. Land use and climate change on the Yamal Peninsula of northwest Siberia: Some ecological and socio-economic implications. Polar Research 18: 367-373.

Forbes, BL, and O Sumina. 1999. Comparative ordination of low arctic vegetation recovering from disturbance: Reconciling two contrasting approaches for field data collection. Arct Antarct Alp Res 31: 389-399.

Forbes, BC, F Stammler, T Kumpula, N Meschtyb, A Pajunen, and E Kaarlejärvi. 2009. High resilience in the Yamal-Nenets social-ecological system, West Siberian Arctic, Russia. Proc Natl Acad Sci 106: 22041-22048.

Forbes, B, MM Fauria, and P Zetterberg. 2010. Russian warming and 'greening' are closely tracked by tundra shrub willows. Glob Chang Biol 16: 1542-1554.

Gadallah, FL, and RP Jefferies. 1995. Comparison of the nutrient contents of the principal forage plants utilized by lesser snow geese on summer breeding grounds. J Appl Ecol 32: 263-275.

Gerhart, KL, RG White, RD Cameron, and DE Russell. 1996. Body composition and nutrient reserves of arctic caribou. Canadian Journal of Zoology 74: 136-146.

Istomin, KL, and MJ Dwyer. 2009. Finding the way: A critical discussion of anthropological theories of human spatial orientation with reference to reindeer herders of northeastern Europe and western Siberia. Curr Anthropol 50: 29-49.

Istomin, KL, and MJ Dwyer. 2010. Dynamic mutual adaptation: Human-animal interaction in reindeer herding pastoralism. Hum Ecol 38: 613-623.

Joly, K, C Nellemann, and I Vistnes. 2006. A re-evaluation of caribou distribution near an oilfield road on Alaska's North Slope. Wild Soc Bull 34: 866-869.

Klokov, KB. 2000. Nenets reindeer herders on the lower Yenisei River: Traditional economy under current conditions are responses to economic change. Polar Research 19: 39-47. 
Kumpula, T, A Pajunen, EM Kaarlejärvi, BC Forbes, and F Stammler. 2011. Land use and land cover change in arctic Russia: Ecological and social implications of industrial development. Glob Environ Chang 21: 550-562

Kumpula, T, BC Forbes, F Stammler, and N Meschtyb. 2012. Dynamics of a coupled system: Multi-resolution remote sensing in assessing socialecological responses during 25 years of gas field development in Arctic Russia. Remote Sensing 4: 1046-1068.

Macias-Fauria, M, BC Forbes, P Zetterberg, and T Kumpula. 2012. Eurasian Arctic greening reveals teleconnections and the potential for novel ecosystems. Nature Climate Change. doi:10.1038/NCLIMATE1558.

Magga, OH, SD Mathiesen, RW Corell, A Oskal, R Benestad, MP Bongo, P Burgess, A Degteva, V Etylen, IMG Eira, RBM Eira, OI Eira, NI Eira, E Førland, C Jaedicke, I Hanssen-Bauer, IV Schuler, D Hendrichsen, D Griffiths, J Gebelein, ECH Keskitalo, V Kryazhkov, V Laptander, AM Magga, NG Maynard, L Moe, C Nellemann, ER Nergård, H Omma, N Oskal, et al. 2011. Reindeer herding, traditional knowledge and adaptation to climate change and loss of grazing land. Arctic Council Ministerial Meeting Report. Fagtrykk Idé AS: Alta.

Myers-Smith, I, BK Arnesen, RM Thompson, and FSIII Chapin. 2006. Cumulative impacts on Alaskan arctic tundra of a quarter century of road dust. Ecoscience 13: 503-510.

Nkedianye, D, J Leeuw, JO Ogutu, MY Said, TL Saidimu, SC Kifugo, DS Kaelo, and RS Reid. 2011. Mobility and livestock mortality in communally used pastoral areas: The impact of the 2005-2006 drought on livestock mortality in Maasailand. Pastoralism 1: 17.

Nellemann, C, and MG Thomsen. 1994. Terrain ruggedness and caribou forage availability during snowmelt on the Arctic Coastal Plain, Alaska. Arctic 47: 361-367.

Nellemann, C, and G Fry. 1995. Quantitative analysis of terrain ruggedness in reindeer winter grounds. Arctic 48: 172-176.

Nellemann, C, and RD Cameron. 1996. Effects of petroleum development on terrain preferences of calving caribou. Arctic 49: 23-28.

Nellemann, C, and RD Cameron. 1998. Cumulative impacts of an evolving oilfield complex on the distribution of calving caribou. Canadian Journal of Zoology 76: $425-1430$.

Ngai, JT, and JL Jefferies. 2004. Nutrient limitation of plant growth and forage quality in Arctic coastal marshes. J Ecol 92: 1001-1010.

Oskal, A, NG Maynard, A Degteva, SD Mathiesen, M Pogodaev, and A Ivanoff. 2010. Oil and gas development in reindeer pastures of northern Eurasia: Impacts and solutions. Poster presented at the State of the Arctic Conference. National Science Foundation: Miami.

Raziq, A, K Verdier, and M Younas. 2011. Rapid change of strategy is necessary for development of dromedary camel pastoralism in the Cholistan desert of Pakistan. Pastoralism 1: 3 .

Sharma, MC, J Chinmay, D Gunjan, and K Hussain. 2007. Mineral nutrition and reproductive performance of the dairy animals: A review. Indian Journal of Animal Science 77: 599-608.

Skarin, AD, Ö Danell, R Bergström, and J Moen. 2004. Insect avoidance may override human disturbances in reindeer habitat selection. Rangifer 24 95-103.

Spaans, B, and P Postma. 2001. Inland pastures are an appropriate alternative for salt-marshes as a feeding area for spring-fattening Dark-bellied Brent Geese Branta bernicla. Ardea 89: 427-440.

Staaland, H, I Brattbak, I Ekern, and K Kildemo. 1983. Chemical composition of reindeer forage plants in Svalbard and Norway. Ecography 6: 109-122.

Stammler, F. 2005. Reindeer nomads meet the market: Culture, property and globalization at the 'End of the land'. Münster: Lit Verlag.

Stammler, F, and E Wilson. 2006. Dialogue for development: An exploration of relations between oil and gas companies, communities and the state. In Special issue on the oil and gas industry local communities and the state, ed. Emma Wilson and Florian Stammler. Oxford/New York: Berghahn. Sibirica 5(2): 1-42.

Stammler, F, and V Peskov. 2008. Building a 'culture of dialogue' among stakeholders in North-West Russian oil extraction. Europa-Asia Studies 60: 831-849.

Stammler, F. 2011. Oil without conflict? The anthropology of industrialisation in Northern Russia. Chapter 10. In Crude domination: An anthropology of oil, ed. A Behrends, SP Reyna, and G Schlee, 243-269. Oxford: Berghahn Books.

YNAO Statistics. 2010. Official statistics received from Territorial'ny organ federal'noy sluzhby gosudarstvennoy statistiki po Yamalo-Neneckomu avtonomnomu okrugu.
Svoboda, J, S Sázelová, PA Kosintsev, V Jankovská, and M Holub. 2011. Resources and spatial analysis at actual Nenets campsites: Ethnoarchaeological implications. J Anthropol Archaeol 30: 30-43.

Turi, JM. 2002. The world reindeer livelihood - current situation, treats and possibilities. In The northern timberline forest: Environmental and socioeconomic issues and concerns, ed. S Kankaanpaa, K Muller-Willie, P Susiluoto, and ML Sutinen, 70-75. Helsinki: Finnish Forest Research Institute.

Tyler, NJC, JM Turi, MA Sundset, KS Bull, MN Sara, E Reinert, N Oskal, C Nellemann, JJ McCarthy, SD Mathiesen, ML Martello, OH Magga, GK Hovelsrud, I Hanssen-Bauer, NI Eira, IMG Eira, and RW Corell. 2007. Sami reindeer pastoralism under climate change: Applying a generalised framework for vulnerability studies to a sub-Arctic social-ecological system. Glob Environ Chang. doi:10.1016/j.gloenvcha.2006.06.001

UNEP. 2001. GLOBIO - Global methodology for mapping human impacts on the biosphere, eds. C. Nellemann, L. Kullerud, I. Vistnes, B.C. Forbes, G.P. Kofinas, B. P. Kaltenborn, O. Grøn, D. Henry Huntingdon, M. Magomedova, C. Lambrechts, T.S. Larsen, P.J. Schei, and R. Bobiwash. Nairobi: United Nations Environmental Programme.

UNEP. 2010. In Protecting Arctic biodiversity, ed. KI Johnsen, B Alfthan, L Hislop, and JF Skaalvik Arendal: United Nations Environment Programme, GRIDArendal. www.grida.no.

Vistnes, I, and C Nellemann. 2001. Avoidance of cabins, roads, and power lines by reindeer during calving. J Wildl Manag 65: 915-925

Vistnes, I, and C Nellemann. 2009. Impacts of human activity on reindeer and caribou: The matter of spatial and temporal scales. Polar Biol 31: 399-407.

Walker, DA, MO Leibman, HE Epstein, BC Forbes, US Bhatt, MK Raynolds, JC Comiso, AA Gubarkov, AV Khomutov, GJ Jia, E Kaarlejärvi, JO Kaplan, T Kumpula, P Kuss, G Matyshak, NG Moskalenko, P Orekhov, VE Romanovsky, NG Ukraientseva, and Q Yu. 2009. Spatial and temporal patterns of greenness on the Yamal Peninsula. Russia: Interactions of ecological and social factors affecting the Arctic normalized difference vegetation index. Environmental Research Letters. doi:10.1088/1748-9326/4/4/045004.

Wolfe, SA, B Griffith, and CAG Wolfe. 2000. Response of reindeer and caribou to human activities. Polar Research 19: 63-73.

doi:10.1186/2041-7136-3-15

Cite this article as: Degteva and Nellemann: Nenets migration in the landscape: impacts of industrial development in Yamal peninsula, Russia. Pastoralism: Research, Policy and Practice 2013 3:15.

\section{Submit your manuscript to a SpringerOpen ${ }^{\circ}$ journal and benefit from:}

- Convenient online submission

- Rigorous peer review

- Immediate publication on acceptance

- Open access: articles freely available online

- High visibility within the field

- Retaining the copyright to your article

Submit your next manuscript at $>$ springeropen.com 